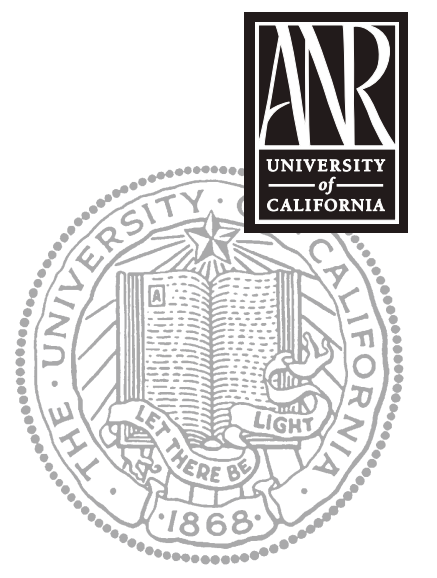

UNIVERSITY OF CALIFORNIA

Division of Agriculture and Natural Resources http://anrcatalog.ucdavis.edu

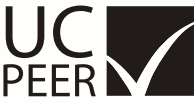

REVIEWED

\title{
Forestry, Forest Industry, and Forest Products Consumption in California
}

SUSANNA LAAKSONEN-CRAIG is former Assistant Director for Programs, University of California Forest Products Laboratory, Richmond; GEORGE E. GOLDMAN is UC Cooperative Extension Specialist, Agricultural and Resource Economics and Policy, UC Berkeley; and WILLIAM MCKILLOP is Professor Emeritus of Forest Science, College of Natural Resources, UC Berkeley.

\section{FOREST RESOURCES}

\section{Forest Cover and Inventory}

California has 39.7 million acres of forestland ${ }^{1}$, almost 40 percent of the land area in the entire state. The timberland ${ }^{2}$ area in the state was 16.7 million acres in 1996, a slight increase from 16.3 million in 1975 . However, the current acreage of timberland is less than the 17.3 million acres reported for 1953. Most of the forestland, as well as timberland, is located in the northern part of the state. The largest timberland areas are in Humboldt, Mendocino, Plumas, Shasta, Siskiyou, and Trinity Counties (Table 1) (Bolsinger 1980; FRAP 2001; Waddell and Bassett 1996, 1997a, 1997b, 1997c, 1997d).

Most of the timberland in California (about 77\%) is softwoods. The prominence of softwoods is even more significant by volume. In 1994 the net volume of sawtimber ${ }^{3}$ on timberland was almost 260 billion board feet (BBF), of which over 240 BBF (94\%) was softwoods. In comparison, in 1975 almost 228 BBF (97 percent) was softwoods. The most abundant species by volume were Douglas-fir (almost $74 \mathrm{BBF}$ ), white fir (more than $45 \mathrm{BBF}$ ), and ponderosa pine (more than $32 \mathrm{BBF}$ ). The most significant hardwoods were tanoak (more than $5 \mathrm{BBF}$ ) and California black oak (more than 3 BBF) (Bolsinger 1980; Waddell and Bassett 1996, 1997a, 1997b, 1997c, 1997d).

According to the latest forest inventory in California in 1994, the net volume of growing stock in California was 55 billion cubic feet (bcf) and the net volume of sawtimber was $258 \mathrm{BBF}$. The net growth of the growing stock was estimated to be $1.3 \mathrm{bcf}$. The distribution of growing stock in different resource areas is shown in Table 2 (Waddell and Bassett 1996, 1997a, 1997b, 1997c, 1997d).

Both the net volume of growing stock and the net volume of sawtimber have increased since 1975, when those figures were 49.7 bcf and $236 \mathrm{BBF}$, respectively. The net growth of growing stock also increased from the 801.6 million cubic feet (mcf) of 1975 (Bolsinger 1980).

\section{Forest Ownership}

The National Forests, managed by the United States Department of Agriculture Forest Service, make up about 53 percent of the timberland area in California, and only about 3 percent is in other public ownership. Private ownership is significant in California: about 25 percent of timberland is owned by forest industry companies, 6 percent by private farmers, and 14 percent by other private parties (California State Board of Equalization 2001). The most significant change in timberland ownership from 1975

1. Forestland is defined as land at least 10 percent stocked by forest trees of any size, including land that formerly had such tree cover and that will be naturally or artificially regenerated (Helms 1998).

2. Timberland (commercial forestland) is defined as land declared suitable for producing timber crops and not withdrawn from timber production by statute or administrative regulation; the minimum level of productivity is often set at $20 \mathrm{ft}^{3} / \mathrm{ac} / \mathrm{yr}\left(1.4 \mathrm{~m}^{3} / \mathrm{ha} / \mathrm{yr}\right)$ (Helms 1998).

3. Sawtimber is trees or logs cut from trees with minimal diameter and length and with stem quality suitable for conversion to lumber (Helms 1998). 
Table 1. Timberland area by county in 1996

\begin{tabular}{|l|r|l|r|l|r|}
\hline County & $\begin{array}{r}\text { 1,000 } \\
\text { acres }\end{array}$ & County & $\begin{array}{r}1,000 \\
\text { acres }\end{array}$ & County & $\begin{array}{r}1,000 \\
\text { acres }\end{array}$ \\
\hline Alameda & 0 & Marin & 19 & San Luis Obispo & 0 \\
\hline Alpine & 85 & Mariposa & 152 & San Mateo & 55 \\
\hline Amador & 104 & Mendocino & 1,303 & Santa Barbara & 1 \\
\hline Butte & 354 & Merced & 0 & Santa Clara & 8 \\
\hline Calaveras & 204 & Modoc & 668 & Santa Cruz & 156 \\
\hline Colusa & 23 & Mono & 183 & Shasta & 1,231 \\
\hline Contra Costa & 0 & Monterey & 26 & Sierra & 450 \\
\hline Del Norte & 320 & Napa & 22 & Siskiyou & 2,188 \\
\hline El Dorado & 636 & Nevada & 354 & Solano & 0 \\
\hline Fresno \& Madera & 572 & Orange & 1 & Sonoma & 303 \\
\hline Glenn & 101 & Placer & 421 & Stanislaus & 0 \\
\hline Humboldt & 1,487 & Plumas & 1,235 & Sutter & 0 \\
\hline Imperial & 0 & Riverside & 35 & Tehama & 410 \\
\hline Inyo & 27 & Sacramento & 0 & Trinity & 1,062 \\
\hline Kern & 148 & San Benito & 11 & Tuolumne & 479 \\
\hline Kings \& Tulare & 391 & San Bernardino & 179 & Ventura & 31 \\
\hline Lake & 180 & San Diego & 47 & Yolo & 0 \\
\hline Lassen & 796 & San Francisco & 0 & Yuba & 112 \\
\hline Los Angeles & 79 & San Joaquin & 0 & Total & 16,649 \\
\hline
\end{tabular}

Source: FRAP 2001 to 2000 was the nearly 10 percent increase in area owned by the forest industry, despite the simultaneous decline in the number of forest industry companies in business. In 1975 the forest industry owned 17 percent of timberland, farmers held 10 percent, and 20 percent belonged to other private owners. The National Forests constituted 50 percent of timberland, and 3 percent was in other public ownership (Bolsinger 1980). The ownership structure, however, changed swiftly. By 1982, 23 percent of timberland was already held by forest industry, 53 percent was in National Forests, and 4 percent was in other public ownership (FRRAP 1988).

The National Forests in California are mostly located in the northern region. The largest areas of privately owned forests are in Humboldt and

Mendocino Counties, but there is also a significant amount of private forestry in Shasta and Siskiyou Counties (California State Board of Equalization 1981-2000, 2001).

\section{ROUNDWOOD MARKETS}

\section{Timber Harvest}

Total timber harvest. In 2000 the California timber harvest was 2.0 BBF (2.1 BBF in 1999),

and the harvest value was $\$ 909$ million (\$764 million in 1999). Currently, the majority of the harvested timber volume originates in private forests. In 2000, only 13.5 percent of the volume (265 million board feet $[\mathrm{MMBF}]$ ) and 7.6 percent of the harvest value (\$69 million) came from public forests. This represents a significant shift from the 1980s when about 40 percent of timber was harvested from public forests (FRRAP 1988, California State Board of Equalization 1991-2000, 2001).

The total timber harvest in California was highest in 1955, at over 6 BBF due to the high post-WWII demand for housing. From 1978 to 1985, the average annual timber harvest in California was about 3.4 BBF, just over half of the average from 1950 through 1960. The timber harvest continued to decline until 1982. After reaching a low point in annual average harvest level in 1982, timber harvest volumes increased quickly, almost doubling by 1988. The decline of public timber harvests since the end of the 1980s is due to increased harvesting restrictions on public lands. This has also had a major effect on the total harvested volume in California (Figure 1) (FRRAP 1988, California State Board of Equalization 1991-2000, 2001). 
Consequently, timber harvest values have decreased, following fairly closely the decline in harvest volumes. Yet despite the decline in timber harvest values, timber is still a significant crop in California. Using the 1999 harvest and commodity values, the harvest value for stumpage (i.e., value of standing trees before harvest, transportation, and processing) was $\$ 764$ million, and timber ranked as California's ninth most valuable commodity after milk and cream, grapes, nursery products, cattle and calves, tomatoes, lettuce, strawberries, and flowers and foliage. Timber harvest value was more than that of, for example, almonds or oranges (California State Board of Equalization 2001, California Department of Food and Agriculture 2001).

Timber harvest by county. The timber harvest values in counties correspond closely to the size of their timberland area. In 2000, the most timber was harvested in Humboldt, Siskiyou, Mendocino, Plumas, and Shasta Counties. Humboldt County alone accounted for almost 20 percent of California's timber harvest (Figure 2). More complete information about timber harvest in thousands of board feet (MBF) volumes in each county can be found in Table 3 (California State Board of Equalization 2001).

Table 3. Timber harvest (volume by county in 2000)

\begin{tabular}{|l|r|l|r|l|r|}
\hline County & MBF & County & MBF & County & MBF \\
\hline Alameda & 0 & Marin & 0 & San Mateo & 4,505 \\
\hline Alpine & 0 & Mariposa & 2,746 & Santa Barbara & 0 \\
\hline Amador & 28,423 & Mendocino & 156,101 & Santa Clara & 3,954 \\
\hline Butte & 85,791 & Merced & 0 & Santa Cruz & 18,414 \\
\hline Calaveras & 49,070 & Modoc & 41,628 & Shasta & 144,640 \\
\hline Colusa & 0 & Mono & 0 & Sierra & 40,848 \\
\hline Contra Costa & 0 & Monterey & 0 & Siskiyou & 193,408 \\
\hline Del Norte & 46,133 & Napa & 649 & Solano & 0 \\
\hline El Dorado & 107,498 & Nevada & 47,250 & Sonoma & 24,157 \\
\hline Fresno & 16,301 & Orange & 0 & Stanislaus & 0 \\
\hline Glenn & 15,522 & Placer & 32,452 & Sutter & 0 \\
\hline Humboldt & 388,886 & Plumas & 154,225 & Tehama & 100,887 \\
\hline Imperial & 0 & Riverside & 0 & Trinity & 72,735 \\
\hline Inyo & 0 & Sacramento & 0 & Tulare & 5,445 \\
\hline Kern & 5,253 & San Benito & 0 & Tuolumne & 61,061 \\
\hline Kings & 0 & San Bernardino & 0 & Ventura & 0 \\
\hline Lake & 6,146 & San Diego & 0 & Yolo & 0 \\
\hline Lassen & 60,566 & San Francisco & 0 & Yuba & 46,767 \\
\hline Los Angeles & 0 & San Joaquin & 0 & & Total \\
\hline Madera & 3,196 & San Luis Obispo & 0 & & $1,965,657$ \\
\hline
\end{tabular}

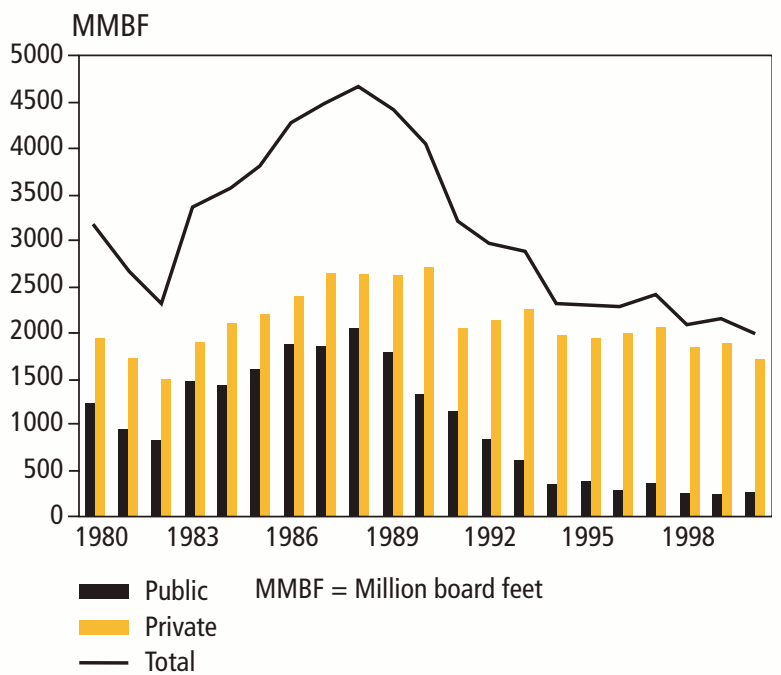

Figure 1. California timber harvest volume 1980-2000 (California State Board of Equalization 1981-2000a, 2001).

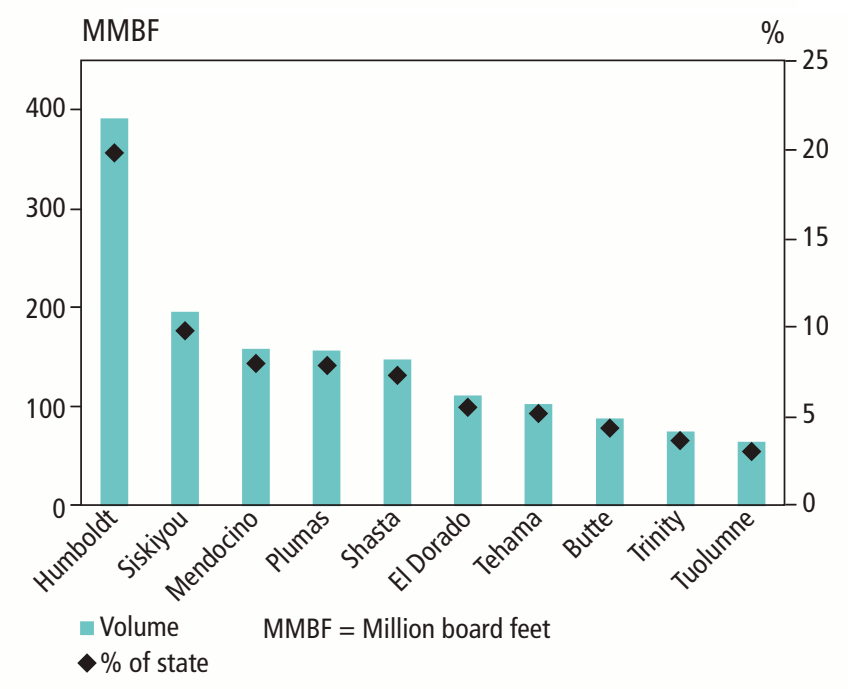

Figure 2. Top ten California counties in timber harvest for 2000 (California State Board of Equalization 2001). 


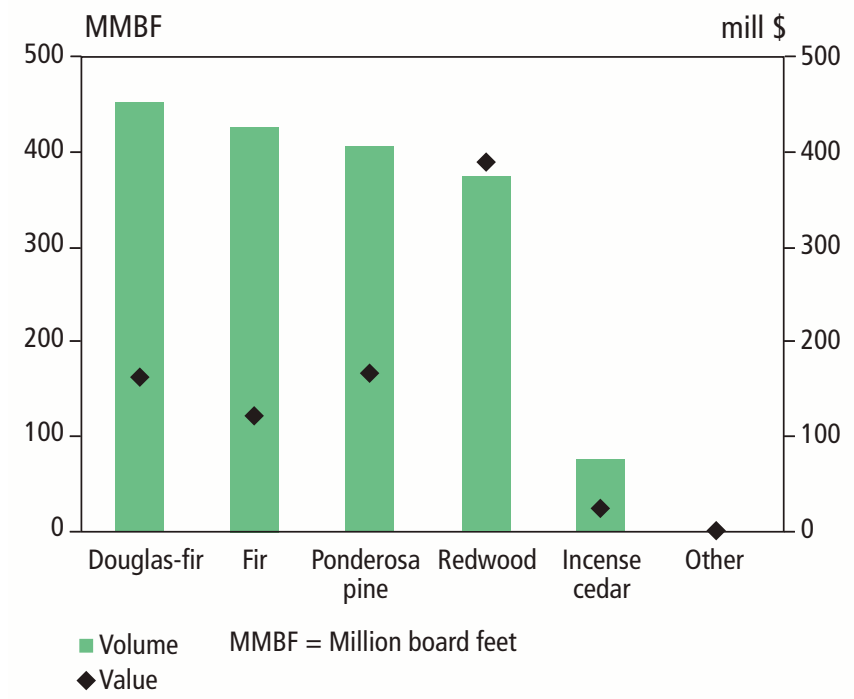

Figure 3. California timber harvest by species, for 2000 (California State Board of Equalization 2001).

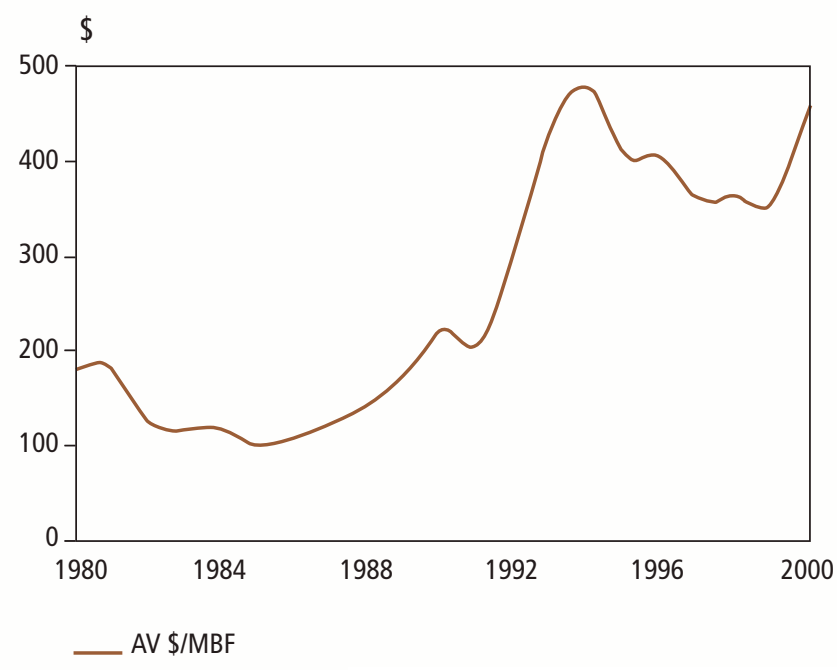

Figure 4. Average harvest value per thousand board feet (MBF), 1980-2000 (California State Board of Equalization, 1981-2000a, 2001).
In 1990 the largest timber volumes were harvested in Humboldt, Mendocino, Siskiyou, El Dorado, and Trinity Counties. The decline in public harvest during the past decade has affected the total timber harvest, especially in counties with large public forest ownership such as Siskiyou, El Dorado, and Plumas (Waddell and Bassett 1996, 1997a, 1997b, 1997c, and 1997d).

When harvest value is considered, the significance of Humboldt County is even greater. Over 30 percent of the state's harvest value comes from Humboldt County, and almost 13 percent originates in Mendocino County. A pattern became established over the decade from 1991 to 2000 in which Humboldt County's share of the California harvest value was more than 20 percent and Mendocino County's more than 10 percent (California State Board of Equalization 2001).

Timber harvest by species. Douglas-fir and true fir, with harvests of $453 \mathrm{MMBF}$ and $428 \mathrm{MMBF}$, respectively, were the most harvested species in California in 2000. These species were followed by ponderosa pine and redwood. Redwood is, however, the most valuable species in California. The value of redwood harvest in 2000 was $\$ 390$ million, which is about 43 percent of the total timber harvest value for California (Figure 3). There were no significant shifts in relative harvest volumes between species in the 1990s. However, Douglas-fir became slightly more predominant toward the end of the decade (California State Board of Equalization 1991-2000, 2001).

\section{Stumpage Prices}

The trends in average harvest value per 1,000 board feet (MBF) can be seen in Figure 4. The decline in the mid1990s was partially due to the harvest of smaller quantities of more-valuable, large-diameter timber. The average harvest value increase at the end of the 1990s was in part caused by higher prices for redwood (California State Board of Equalization 1990-2000, 2001).

\begin{tabular}{|c|c|c|c|c|c|c|c|}
\hline Agency & 1993 & 1994 & 1995 & 1996 & 1997 & 1998 & 1999 \\
\hline \multicolumn{8}{|c|}{ USDA Forest Service } \\
\hline Price (\$/MBF) & 229.73 & 193.49 & 109.30 & 117.08 & 105.52 & 81.51 & 84.57 \\
\hline Volume (MBF) & 651,282 & 539,006 & 453,066 & 480,224 & 539,298 & 400,368 & 314,540 \\
\hline \multicolumn{8}{|c|}{ U.S. Bureau of Land Management } \\
\hline Price (\$/MBF) & 279.24 & 60.29 & 221.21 & 275.03 & 295.87 & 304.91 & 352.57 \\
\hline Volume (MBF) & 7,876 & 18,570 & 5,733 & 13,780 & 81 & 234 & 3,483 \\
\hline \multicolumn{8}{|c|}{ U.S. Bureau of Indian Affairs } \\
\hline Price (\$/MBF) & 331.19 & 455.66 & 525.84 & 455.66 & NA & 367.48 & 428.31 \\
\hline Volume (MBF) & 12,867 & 14,576 & 15,328 & 14,576 & NA & 10,253 & 6,980 \\
\hline \multicolumn{8}{|c|}{ State of California } \\
\hline Price (\$/MBF) & 629.34 & 596.06 & 428.51 & 460.02 & NA & NA & 593.51 \\
\hline Volume (MBF) & 12,200 & 10,683 & 49,193 & 33,747 & NA & NA & 25,610 \\
\hline
\end{tabular}

Source: Warren 2000, 2001
The average stumpage price of timber from the publicly owned or managed lands in California has decreased since the beginning of the 1990s (Table 4). Unfortunately, the data series is too short to show whether there was an upward movement in prices similar to that in average harvest values in 1999 and 2000. In general, the USDA Forest Service prices are more representative than the others due to the large volumes sold by the Forest Service. More 


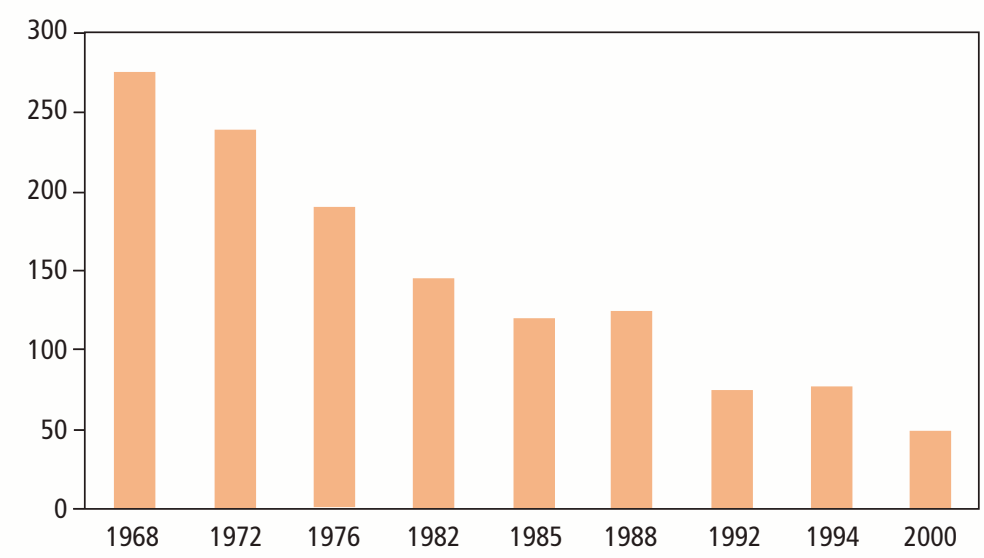

Figure 5. Number of mills (including sawmills, veneer and plywood mills, board mills, and pulp mills) in California, 1968-2000 (Ward 1995, Warren 2001).

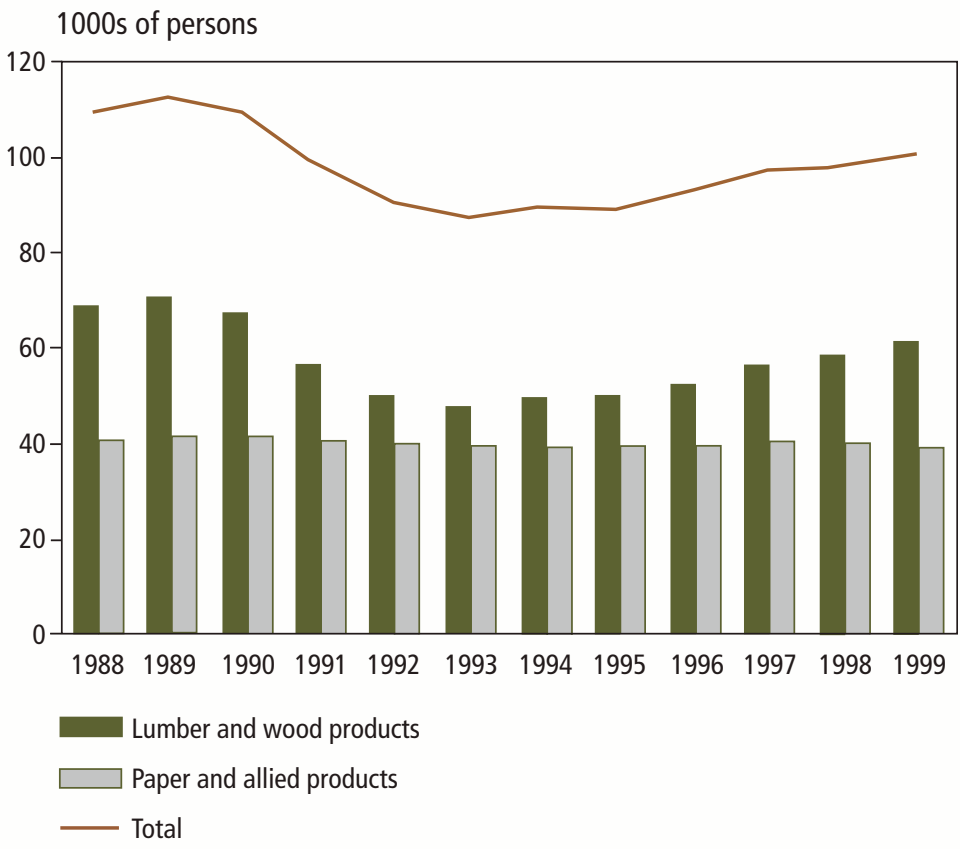

Figure 6. Forest products industry employment in California, 1988-1999 (Warren 2000, 2001). detailed information on stumpage prices by species for sawtimber sold from National Forests in the Pacific Southwest can be found in Appendix A (Warren 2000, 2001).

\section{FOREST PRODUCTS INDUSTRY}

\section{Industry Characteristics}

Number of mills. The number of forest product mills in California has decreased significantly in the past few decades, reflecting the consolidation of the forest products industry and the subsequent closures of small mills (Figure 5). This declining trend has been apparent in all branches of the forest industry; the effect of closures on production volume, however, has been uneven across the industry. The number of sawmills dropped from 93 in 1988 to 53 in 1994, and then further to 42 mills by the end of 2000. In 1994 there were four veneer and plywood mills in California, but by 2001 none were left in the state. Only a few medium density fiberboard (MDF) plants remain.

There were two pulp mills left in California in 2000, but no significant paper production. However, some paperboard and specialty products are produced, and there is a considerable amount of converted paper product manufacturing in California. Recent developments in forestry and in the primary forest industry (e.g., consolidations, mergers, and closings of small, less-efficient plants) indicate that the number of mills will decrease even further in the future as consolidation continues (Ward 1995; Warren 2000, 2001).

Forest industry employment. The decline in the number of mills and in the volume of production in California has had a direct effect on employment in wood product manufacturing as well as in paper manufacturing. The decline in employment has followed more closely the trends in production volumes, however, and it has not been as pronounced as the decline in the number of mills. The number of workers decreased for about 20 years until the beginning of the 1990s, but has been slowly increasing since then (Figure 6).

The production of lumber and wood products employs more than half of the workforce in the forest industry, and the recent upward trend in total employment in this industry took place in this sector. Since the 1970s, the number of workers in the paper industry has remained the same at about 40,000 (Warren 2000, 2001).

Employment in the forest products industry plays a vital role in several counties in Northern California (Table 5). Although the number of people employed in the industry in these Northern California counties is a small percentage of total forest 
industry employment in California, the economies of these counties have traditionally been very much dependent on the forest industry. In recent years their economies have become more diversified, but forestry and the forest industry are still extremely important. In 1999, for example, the total number of employees in wood product manufacturing alone made up 12 percent of all employment in Plumas County and 11 percent in Tehama County.

Forest industry costs. Cost comparisons between 1993 through 1996 and 1997 through 1999 are somewhat difficult due to a switch from Standard Industrial Classification (SIC) codes to North American Industry Classification System (NAICS) codes. Nevertheless, it is still obvious that the raw material costs (about $80 \%$ of total costs) both in wood product manufacturing and in paper manufacturing are significantly higher than either payroll (15\%) or capital expenditure (5\%) costs (Figures 7 and 8).

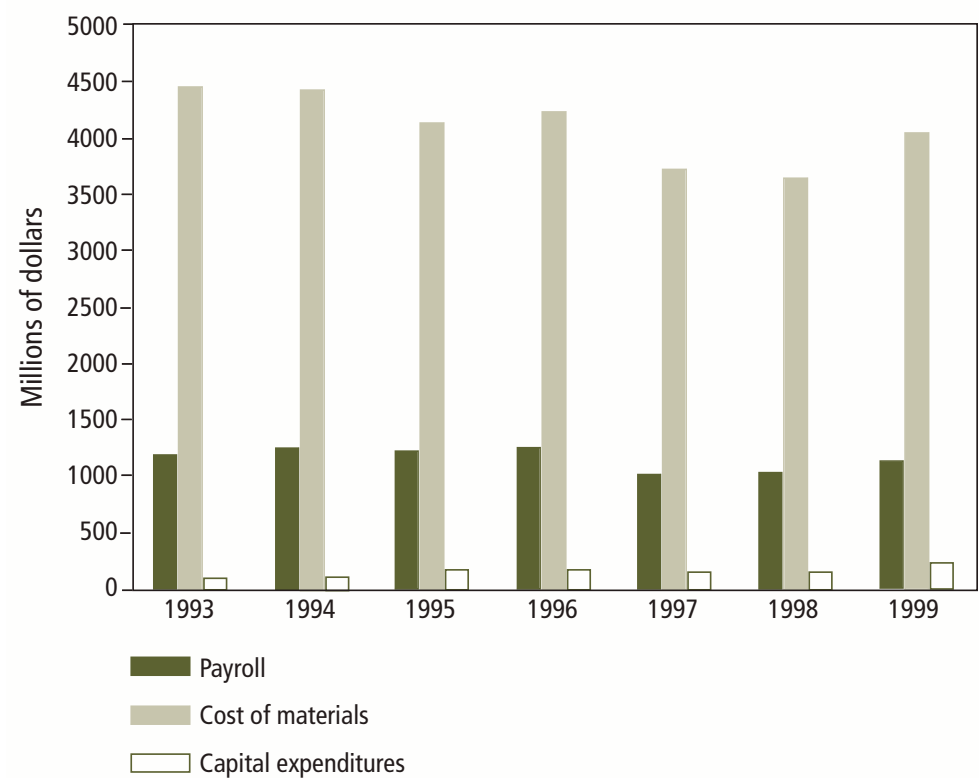

Figure 7. Labor, material, and capital costs in wood product manufacturing (U.S. Census Bureau 1995-2000a, 2001).

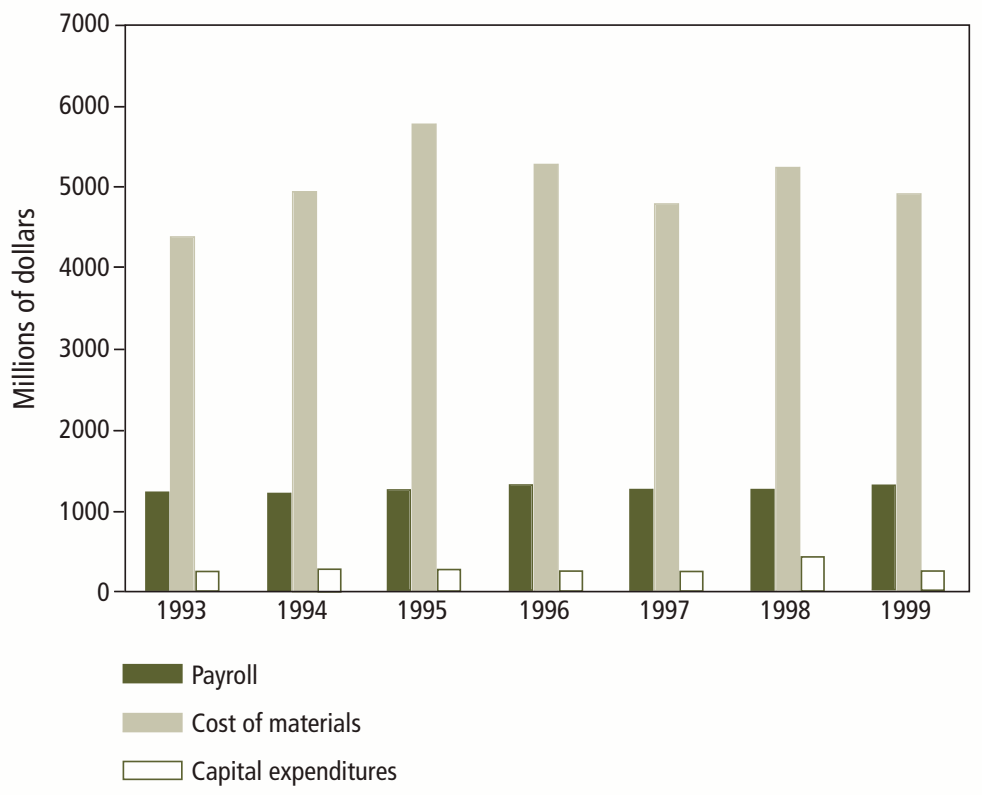

Figure 8. Labor, material, and capital costs in paper manufacturing (U.S. Census Bureau 1995-2000a, 2001).
Appendix B has more detailed information about industry costs (U.S. Census Bureau 1995-2000a, 2001).

The cost structures in national and state forest industries are fairly similar except for a slight difference in productivity. In wood products manufacturing in 1999, for example, each worker on the national level contributed about $\$ 166,000$ to the total value of shipments, whereas in California this figure was $\$ 160,000$. This difference is probably due primarily to the difference in size of production facilities. In paper manufacturing, the industry structure in California is so different that this kind of com-

\section{Table 5. Employment in wood products* manufacturing in 14 selected "timber counties" in 1990 and 1999}

\begin{tabular}{|c|c|c|}
\hline County & $\begin{array}{c}\text { Employed } \\
\text { in } 1990^{*}\end{array}$ & $\begin{array}{l}\text { Employed } \\
\text { in 1999* }\end{array}$ \\
\hline Butte & 1,803 & 738 \\
\hline Del Norte & 432 & 20-99 \\
\hline Humboldt & 4,055 & 3,073 \\
\hline Lassen & 654 & 311 \\
\hline Mendocino & 2,975 & 1,638 \\
\hline Modoc & 133 & 0 \\
\hline Nevada & 254 & 70 \\
\hline Plumas & 787 & 548 \\
\hline Shasta & 2,489 & 836 \\
\hline Sierra & 165 & $100-249$ \\
\hline Siskiyou & 1,452 & 430 \\
\hline Tehama & 1,714 & 1,238 \\
\hline Trinity & 410 & $100-249$ \\
\hline Yuba & 558 & 506 \\
\hline "Timber counties" total & 17,881 & \\
\hline California total & 66,468 & 39,999 \\
\hline
\end{tabular}

Sources: McWilliams and Goldman 1994, U.S. Census Bureau 2000b *In 1990, employed in the lumber and wood products industry (SIC 2400); in 1999, employed in wood products manufacturing (NAICS 321). Does not include forestry. 
parison between national and state figures is not meaningful (U.S. Census Bureau 1995-2000a, 2001).

\section{Lumber Production}

Softwood lumber production in California reached its highest-ever level in 1988 at almost 5.7 BBF (Figure 9). Production then decreased, falling to 3.2 BBF in 1995. Production stayed relatively stable at or around this level during the second half of the 1990s. In 1999 production was slightly over 3.2 BBF. The estimated wholesale value of this production was over $\$ 1.6$ billion. Douglas-fir, hem-fir, and redwood have been, and still are, the most predominant lumber species, whereas ponderosa pine lumber production has decreased. Detailed production figures by species can be found in Appendix C (WWPA 1999).

Hardwood lumber is also produced in California, but there are no comprehensive statistics concerning this sector. In 1999, Shelly et al. estimated California's hardwood lumber production at about $4 \mathrm{MMBF}$ per year.

The value of shipments in sawmilling and wood preservation ${ }^{4}$ in 1999 was $\$ 1.87$ billion, slightly down from 1998 and 1997 (U.S. Census Bureau 1995-2000a, 2001).

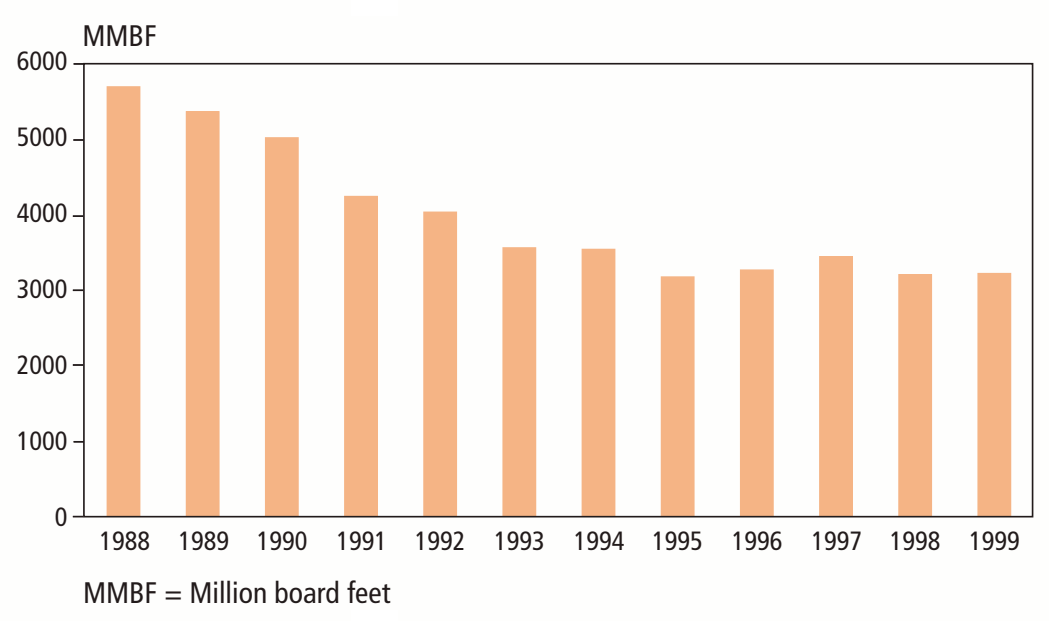

Figure 9. Softwood lumber production in California, 1988-1999 (WWPA 1999).

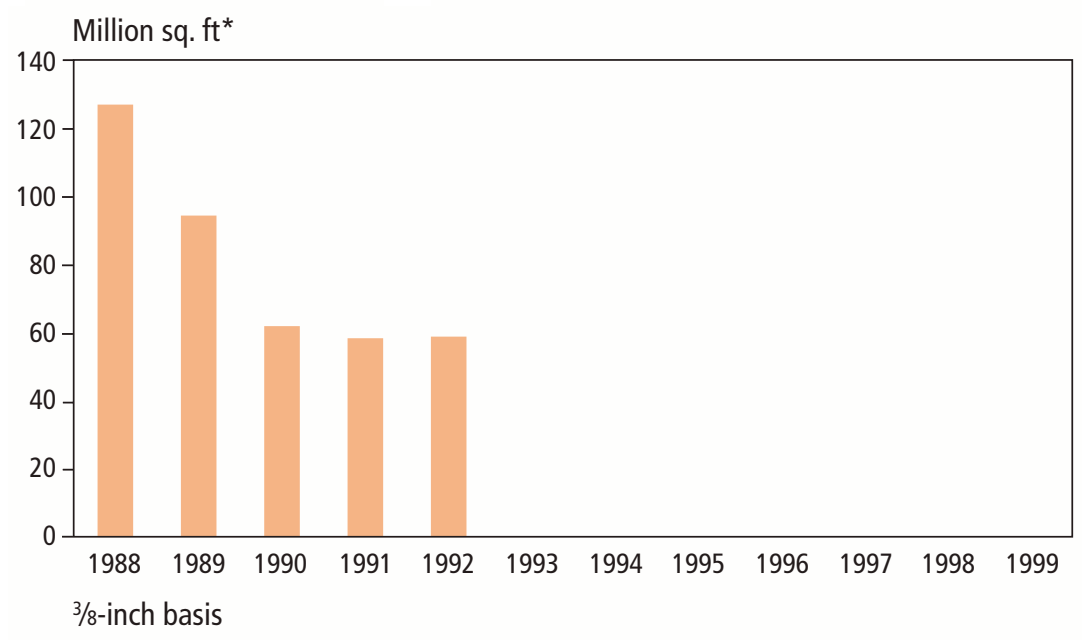

Figure 10. Structural panel board production in California, 1988-1999 (Warren 2000).

\section{Board Production}

Structural panel board ${ }^{5}$ production declined from the end of the 1980s through 1992, and there has been no production since then (Figure 10) (Warren 2000, 2001). A limited amount of medium density fiberboard is produced in the state.

The value of shipments in veneer, plywood, and engineered wood product manufacturing ${ }^{6}$ in 1999 was $\$ 967$ million. This constituted a 28 percent increase over 1998 (U.S. Census Bureau 1995-2000a, 2001).

\section{Pulp, Paper, and Paperboard Production}

Pulp production is minimal in California. In 2000 there were only two operating pulp mills. There is also very little paper production. There are a few paperboard production facilities in the state, mostly producing kraft. There are some production facilities for specialty products and several converted paper product manufacturing plants. The California production of paper and paperboard is insignificant compared to the state's consumption of those products.

According to the U.S. Census Bureau (2001), the values of shipments from pulp, paper, and paperboard mills ${ }^{7}$ in 1999 was $\$ 1.7$ billion, and the value from converted paper product manufacturing ${ }^{8}$ was $\$ 6.9$ billion.

4. North American Industry Classification System 3211

5. Structural panel board includes plywood, wafer board, and oriented strand board (OSB).

6. North American Industry Classification System 3212

7. North American Industry Classification System 3221

8. North American Industry Classification System 3222 


\section{Forest Products Markets}

The majority of the lumber produced in California stays within the state. For example, in 1999 about two-thirds of the 3.2 BBF of lumber production was consumed in California. Around 20 percent was transported to other western states, and about 10 percent to other U.S. states. Only about 1 percent of California-produced lumber was exported. The most common distribution channels were independent wholesalers: almost 60 percent of production was marketed this way. The main mode of transportation was by truck (WWPA 1999).

Large quantities of lumber are also brought into California from other U.S. states (Figure 11) and from Canada. California is the largest single market for western lumber. In 1999 the state received over 26 percent of all western shipments. At about 2,020 MMBF, most of the imported lumber comes from Oregon, and about $760 \mathrm{MMBF}$ originates in Washington. (WWPA 1999).

Besides the lumber shipments from the western states, in 1999 about 235 MMBF of southern pine was shipped to California (SFPA Industry Statistics 2000). Due to inadequate statistics, it is difficult to assess how much softwood or hardwood lumber from other U.S. states is exported to California in any given year.

Canada is the world's largest lumber exporter and a majority of its lumber is exported to the United States. The combined softwood and hardwood lumber exports from Canada directly to California in 1999 were 383 MMBF (Statistics Canada 2001). The volume of Canadian lumber consumed in California probably is significantly higher, but some of the lumber is shipped to California through other states, such as Washington and Oregon, and so appears in volumes received in California from these states. Lumber is also imported from other countries, but documenting these trade flows is difficult because most countries do not separate the U.S. states in their customs statistics; they simply show total exports to the United States.

Information concerning markets for boards, paperboard, and other specialty products are not readily available. Due to the scale of these operations, it is likely that most of California's production is also consumed in California.

\section{Energy Production}

The California forest industry also produces energy from woody biomass (Figure 12). The peak years in the biomass energy industry came in the beginning of the 1990s

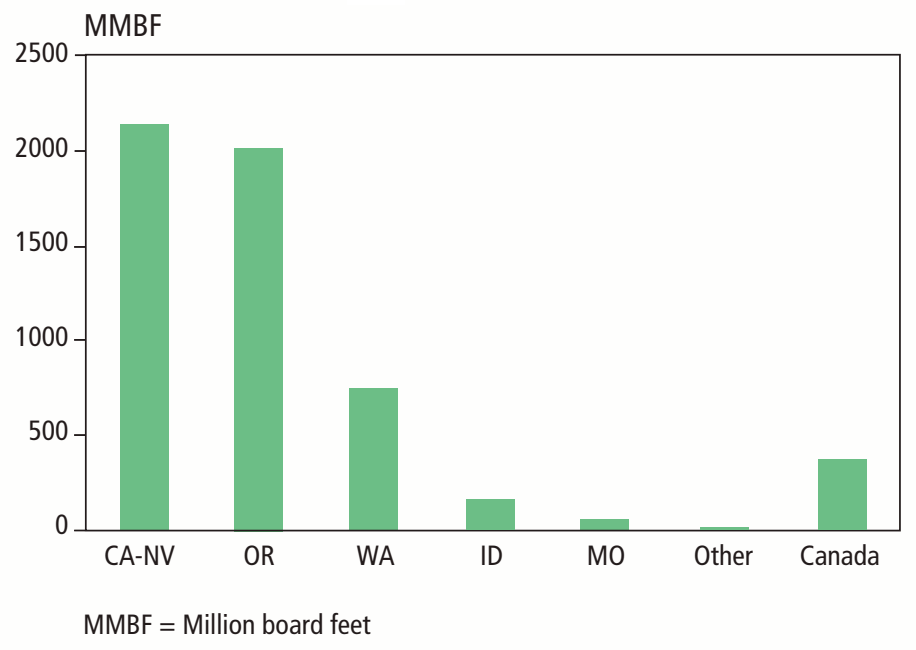

Figure 11. Origin of Western and Canadian lumber produced in or shipped to California in 1999 (WWPA 1999, Statistics Canada 2001). ("Western" includes Arizona, California, Colorado, Idaho, Montana, Nevada, New Mexico, Oregon, South Dakota, Utah, Washington, and Wyoming. There was no lumber production in Nevada in 1999.) when more than 10 million tons (5.5 million bone dry tons) per year of solid waste were converted into 3 percent of the state's electricity supply of 240,000 gigawatt-hours (GWh) (Morris 1999, California Energy Commission 2001). In 2000, the in-state biomass and waste-based installed capacity was 936 megawatts (MW), with actual energy generation of $6,000 \mathrm{GWh}$, about 2 percent of the total electricity generation in California. Energy generation had risen slightly from 1999, when 5,700 GWh were produced from biomass and waste. Sufficient resources are available to allow these numbers to increase substantially: the total estimated biomass resource potential of California is approximately 47 million bone dry tons (California Energy Commission 2001, 2002).

The California Public Utilities Commission's initial 1994 proposal to restructure the electricity market and the subsequent passing of comprehensive electricity utility restructuring legislation 


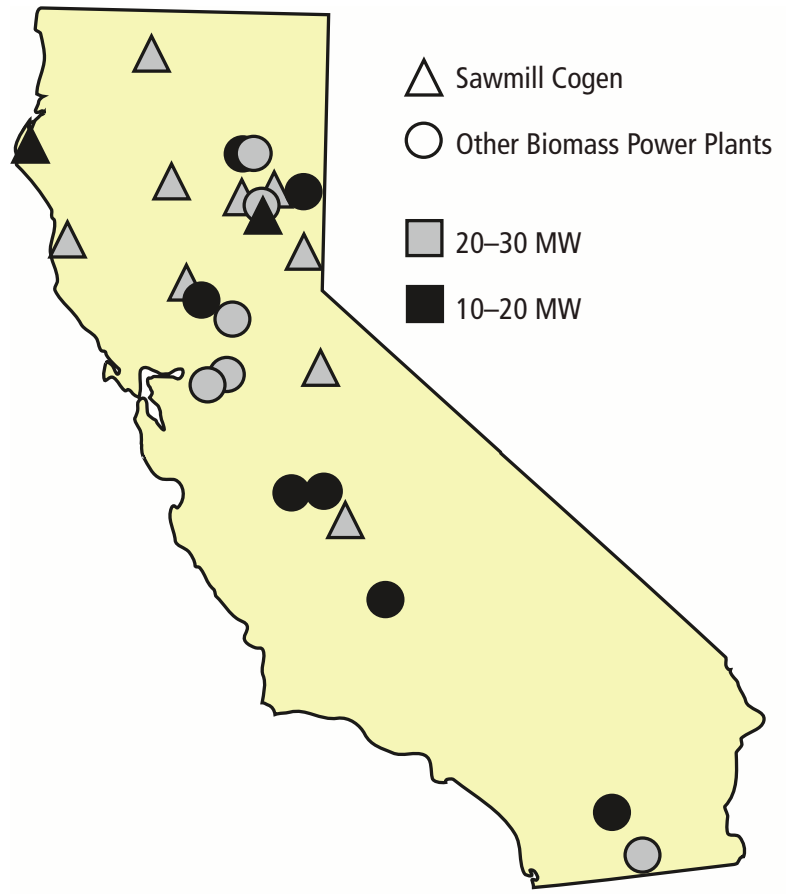

Figure 12. Biomass-based energy production in California in 2000 (Bellis 2001).
(Assembly Bill 1890) have had, however, a profound impact on California's biomass energy industry. AB 1890 called upon the Energy Commission to create a program that would enable the renewable energy sector to compete in a deregulated market, and it recognized the valuable environmental services provided by biomass generation. Before the electricity market crisis began in 2000, the Energy Commission's Renewable Energy Policy was instrumental in increasing the supply and demand of renewables within the market-based system. The crisis led to the elimination of direct access and caused financial difficulties for investor-owned utilities, though, and as a result there is currently no buyer for much of California's new renewable resources (Morris 1999, California Energy Commission 2002).

\section{ECONOMIC IMPACT OF THE FOREST PRODUCTS INDUSTRY}

\section{California}

The direct economic impact of the California forest products industry in terms of jobs created, wages paid, and tax revenue generated is fairly small in the state economy. The indirect effects, however - that is, the multiplied amounts of income, employment, and sales in other industries and sectors as a result of economic activity in the forest industry are more significant. The greater the interdependence of different sectors in the economy, the greater the multiplier effects.

We have chosen to use the IMPLAN ${ }^{9}$ system to calculate the multiplier effects of the forest products industry in California. These multiplier effects include the processing of California timber into final products and also the processing in California of timber or already-processed wood products from other states into final products.

A summary of the economic effects of the forest products industry in California is included in Table 6, and more detailed results can be found in Appendix D. In 1999, the amount of personal income in California generated directly or indirectly as a result of economic activity in the forest products industry was almost $\$ 12.4$ billion ${ }^{10}$. The comparable figure for 1992 was $\$ 11.4$ billion. Nevertheless, in 1999 the number of workers employed in the forest products industry or in other sectors as a result of the economic output of the forest products industry was 227,000 , as compared to more

Table 6. The economic impact of the forest products industries in California in 1999

\begin{tabular}{|c|c|c|c|c|}
\hline Economic sector & $\begin{array}{l}\text { Sales from } \\
\text { production \& } \\
\text { processing }\end{array}$ & $\begin{array}{l}\text { Personal } \\
\text { income }\end{array}$ & Value added & Number of jobs \\
\hline & \multicolumn{4}{|c|}{$\longrightarrow \$ 1000$} \\
\hline Forest products & $15,205,146$ & $12,372,026$ & $13,346,041$ & 227,042 \\
\hline California total & - & $1,093,196,182$ & $1,229,098,000$ & $15,731,700$ \\
\hline$\%$ of total of all industries in California & - & $1.13 \%$ & $1.09 \%$ & $1.44 \%$ \\
\hline
\end{tabular}

9. The IMPLAN (Impact Analysis for Planning) system was created by the USDA Forest Service to estimate the economic input-output models for different regions. Using a large database of secondary published data and algorithms, IMPLAN provides detailed economic multipliers for all sectors of the economy.

10. All dollar amounts are in current dollars. 
Table 7. The economic impact of the forest products industries in Northern California's "timber counties" * in 1999

\begin{tabular}{|c|c|c|c|c|}
\hline & $\begin{array}{l}\text { Sales from } \\
\text { production \& } \\
\text { processing }\end{array}$ & $\begin{array}{l}\text { Personal } \\
\text { income }\end{array}$ & $\begin{array}{l}\text { Value } \\
\text { added }\end{array}$ & $\begin{array}{l}\text { Number } \\
\text { of jobs }\end{array}$ \\
\hline \multicolumn{5}{|c|}{$\longrightarrow 1,000$} \\
\hline Forest products & $3,281,699$ & $2,693,509$ & $2,925,324$ & 59,217 \\
\hline California total & - & $20,323,456$ & $25,242,285$ & 379,850 \\
\hline$\%$ of total of all industries in "timber counties" & - & $13.25 \%$ & $11.59 \%$ & $15.59 \%$ \\
\hline
\end{tabular}

*The fourteen "timber counties" included are Butte, Del Norte, Humboldt, Lassen, Mendocino, Modoc, Nevada, Plumas, Shasta, Sierra, Siskiyou, Tehama, Trinity, and Yuba.

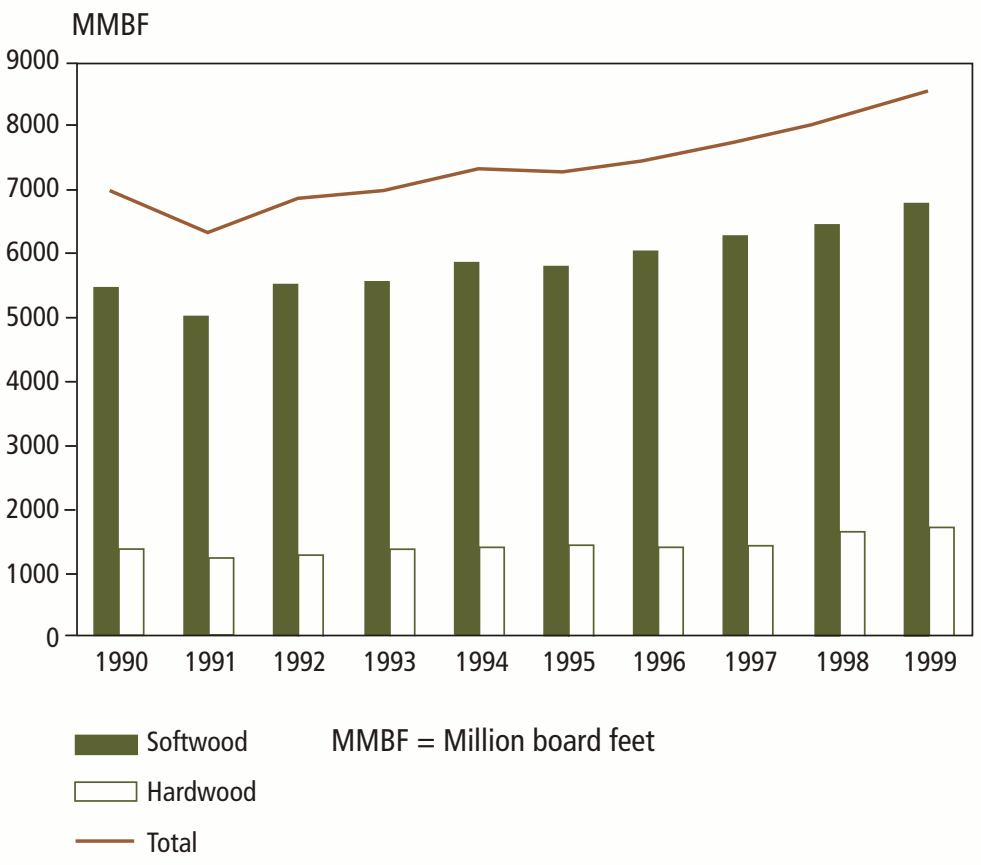

Figure 13. Lumber consumption in California, 1990-1999.

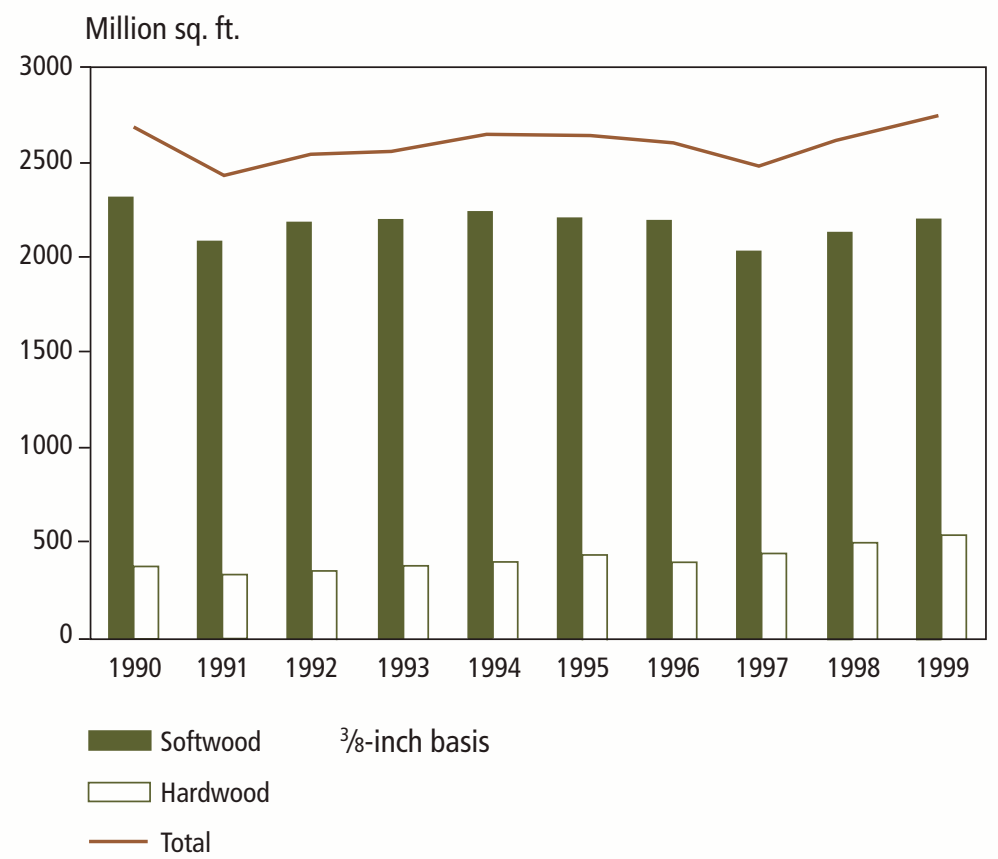

Figure 14. Plywood consumption in California, 1990-1999. than 258,000 in 1992 (McWilliams and Goldman 1994).

A third measure used for economic impacts, besides personal income and number of jobs, was value added. The total value added corresponds to the value of goods and services sold by the sector in question minus the cost of inputs and services, without labor, required to produce those goods. The value added in 1999 was more than $\$ 13.3$ billion, whereas the 1992 value added was more than $\$ 12.2$ billion (McWilliams and Goldman 1994).

The forest products industries represent a small percentage of the overall California totals. Using any of the three measures, the industry's contribution to the California total is only about 1 percent for 1999 .

\section{Northern California}

Although the significance of the forest products industry is fairly small at the state level, it is extremely important to many local economies in Northern California. In 1999 in so-called timber counties, the forest products industry generated about 13 percent of personal income (about 18 percent in 1992), 11 percent of value added (about 16 percent in 1992), and 16 percent of jobs (about 22 percent in 1992) (Table 7). More detailed information can be found in Appendix E (McWilliams and Goldman 1994).

\section{FOREST PRODUCTS CONSUMPTION}

\section{Lumber Consumption}

The exact consumption of lumber and other forest products is difficult to calculate on a state level since there are no comprehensive public statistics of forest product trade flows across state borders. Therefore, we calculated our estimates for total consumption of forest products in California (Figures 13, 14, 15, and 16) in two different ways using existing information 


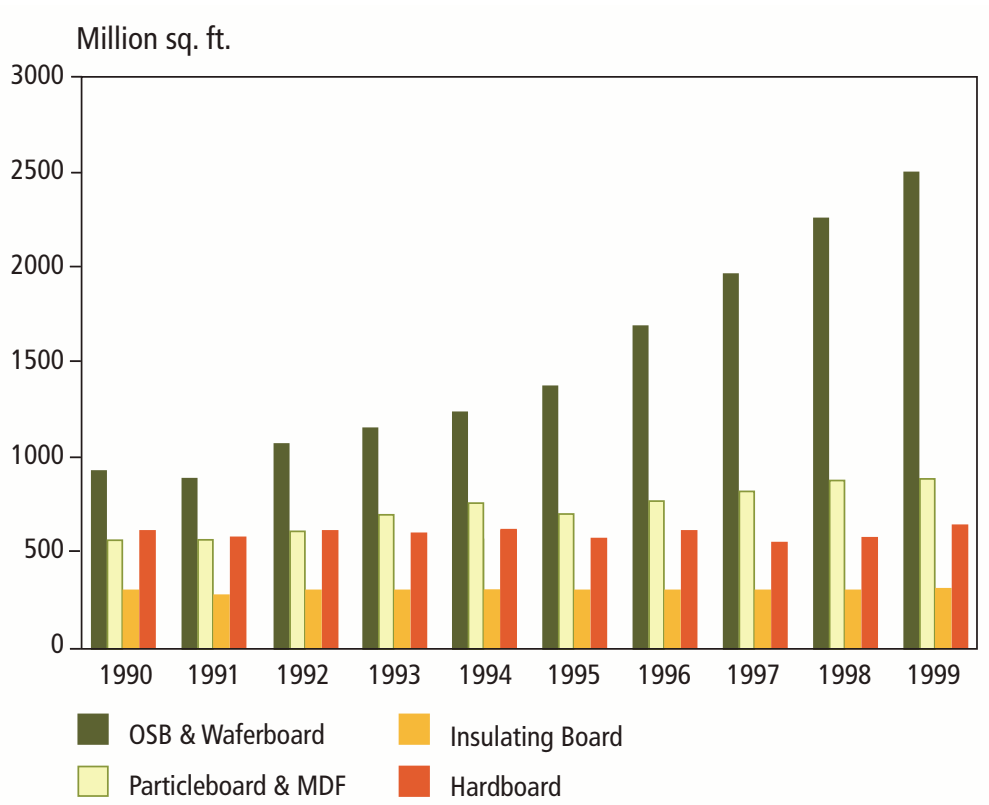

Figure 15. Board consumption in California, 1990-1999. (For OSB and waferboard, the figures are income based. OSB and waferboard statistics use $3 / 8$-inch basis, particleboard and MDF statistics use $3 / 4$-inch basis, insulating board statistics use $1 / 2$-inch basis, and hardboard statistics use $1 / 8$-inch basis.)

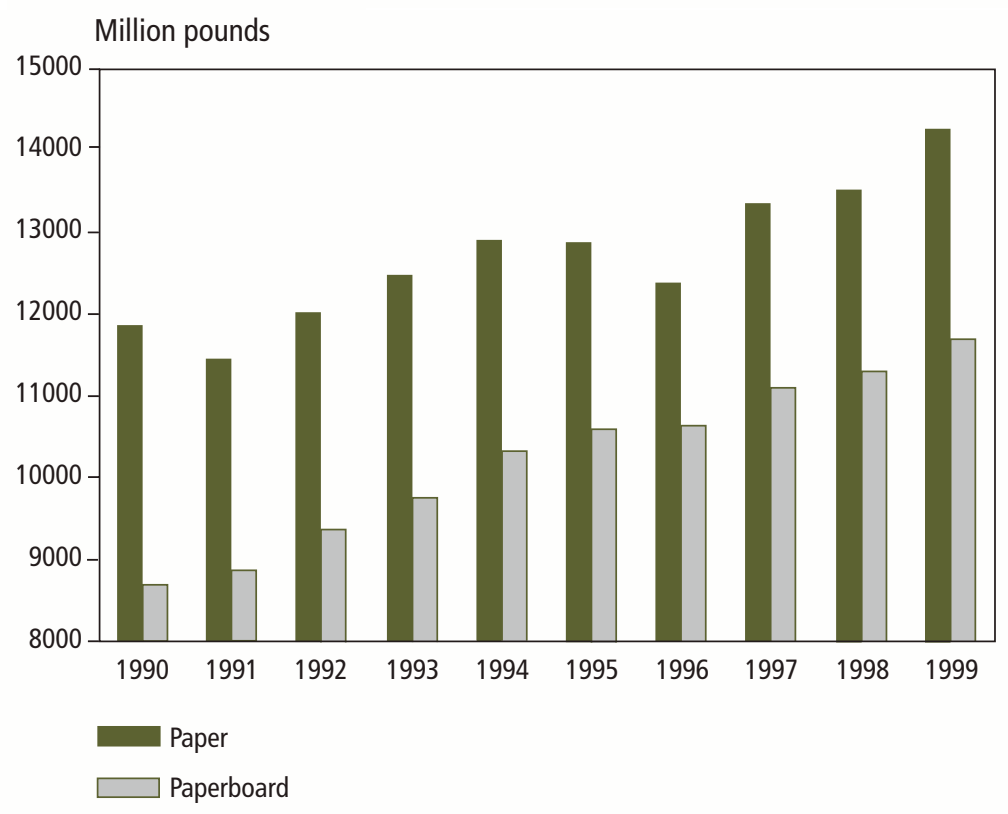

Figure 16. Paper and paperboard consumption in California, 1990-1999. about forest products consumption in the United States as well as population and gross national and state products ${ }^{11}$. All of the figures in this section on lumber consumption show per capita-based consumption: that is, the average U.S. per capita consumption multiplied by the figure for California's total population.

Using this method, we established a total per capita-based lumber consumption in California for 1999 of about 8.5 BBF. The majority of this, almost $6.8 \mathrm{BBF}$, was softwood lumber, with about 1.7 BBF of hardwood lumber. Consumption grew steadily in the 1990s, especially at the end of the decade. The booming economy and increased building activity caused a rapid increase in lumber consumption. Income-based consumption estimates indicate an even higher consumption rate than the per capita figures. According to incomebased calculations, California lumber consumption in 1999 was about 9 BBF.

\section{Board Consumption}

Unlike lumber consumption, the per capitabased total plywood consumption in California stayed relatively constant during the 1990s. In 1999 plywood consumption was about 2.7 billion square feet (bsqft), of which 2.2 bsqft was softwood and 0.5 bsqft was hardwood. Consumption slumped slightly in 1991 and in 1997, but a high level of building activity increased plywood consumption toward the end of the 1990s. As is the case with lumber, 1999 income-based consumption estimates for plywood indicate even higher figures for consumption: about 2.9 bsqft.

Oriented strand board (OSB) has become progressively more popular in the building industry because it is less expensive than plywood and other alternative materials and because of its availability. Oriented strand board consumption was less than 1 bsqft at the beginning of the 1990s, but by the end of the decade consumption was at almost $2.5 \mathrm{bsqft}$.

11. Due to the lack of comprehensive statistics concerning the forest products trade between individual states, the consumption of different forest products in California was estimated in two indirect ways. The per capita-based consumption was calculated by multiplying the average U.S. per capita consumption with California population: (QUS $\left.+\mathrm{M}_{\mathrm{US}}-\mathrm{X}_{\mathrm{US}}\right) / \mathrm{POP}_{\mathrm{US}}{ }^{*} \mathrm{POP}_{\mathrm{CA}}$. The income-based approach utilizes information about U.S. consumption and California's share of the U.S. gross national product of the total: $\left(\mathrm{Q}_{\mathrm{US}}+\mathrm{M}_{\mathrm{US}}-\mathrm{X}_{\mathrm{US}}\right)^{*}\left(\mathrm{GSP}_{\mathrm{CA}} / \mathrm{GNP}_{\mathrm{US}}\right)$. The true consumption is very likely to be somewhere between these two estimates (Howard 2001; U.S. Department of Commerce, Bureau of Economic Analysis 2001a, 2001b; U.S. Census Bureau 2001).

Qus=U.S. production

$\mathrm{M}_{\mathrm{US}}=\mathrm{U} . S$. imports $\mathrm{X}_{\mathrm{US}}=\mathrm{U} . \mathrm{S}$. exports POP $_{U S}=$ U.S. population $\mathrm{POP}_{\mathrm{CA}}=\mathrm{CA}$ population $\mathrm{GNP}_{\mathrm{US}}=\mathrm{U}$.S. gross national product $\mathrm{GSP}_{\mathrm{CA}}=\mathrm{CA}$ gross state product 
There was a slight increase in the consumption of particleboard and medium density fiberboard during the 1990s. By 1999 consumption was about 896 million square feet (msqft) compared to about 569 msqft in 1990. The consumption of hardboard and insulating board stabilized at around 620 and $300 \mathrm{msqft}$, respectively. In 1999 hardboard consumption was 654 msqft and insulating board consumption was 308 msqft.

\section{Paper and Paperboard Consumption}

Since consumption of paper and paperboard follows general economic activity fairly closely, it is not surprising that the consumption of paper and paperboard increased in California during the 1990s. Paper consumption in California was about 11.8 billion pounds in 1990 and about 14.2 billion pounds in 1999. Although it is not possible to separate paper consumption into different product groups using this data, consumption patterns in California most likely followed the overall patterns of North America and Europe, for which data are available (e.g., Howard 2001). In those

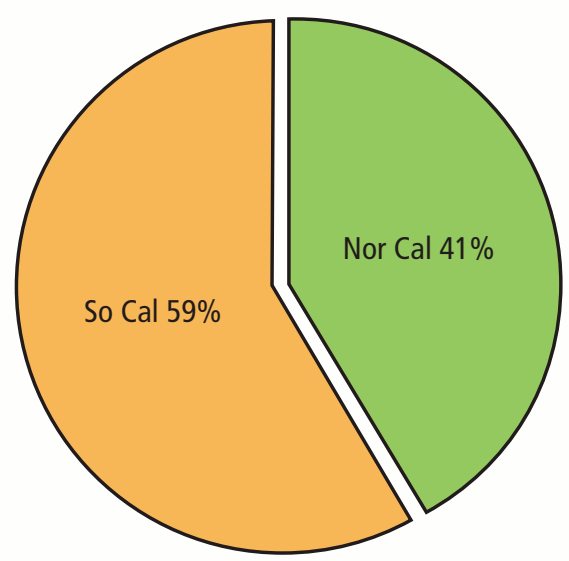

Figure 17. Statewide taxable sales of lumber and building materials (sales for resale are excluded) (California State Board of Equalization 2000b). larger economies, a significant portion of the increase in paper consumption was attributable to an increase in consumption of printing and writing papers, excluding newsprint. The increase in newsprint consumption has been very modest since the mid 1980s (Hetemäki 1999), most likely due to the increased accessibility of news media and other publications online.

Paperboard consumption was about 11.7 billion pounds in 1999 compared to almost 8.7 billion pounds in 1990. The majority of this considerable increase in paperboard consumption is probably due to an increase in product packaging.

\section{EXPENDITURE ON FOREST PRODUCTS}

\section{Taxable Sales of Lumber and Building Materials}

Figures of expenditure on lumber and building materials were used to study the significance of forest products consumption for consumers. In 1999 the taxable sales of lumber and building materials were $\$ 14.1$ bil-

lion, about 3.6 percent of total taxable sales in

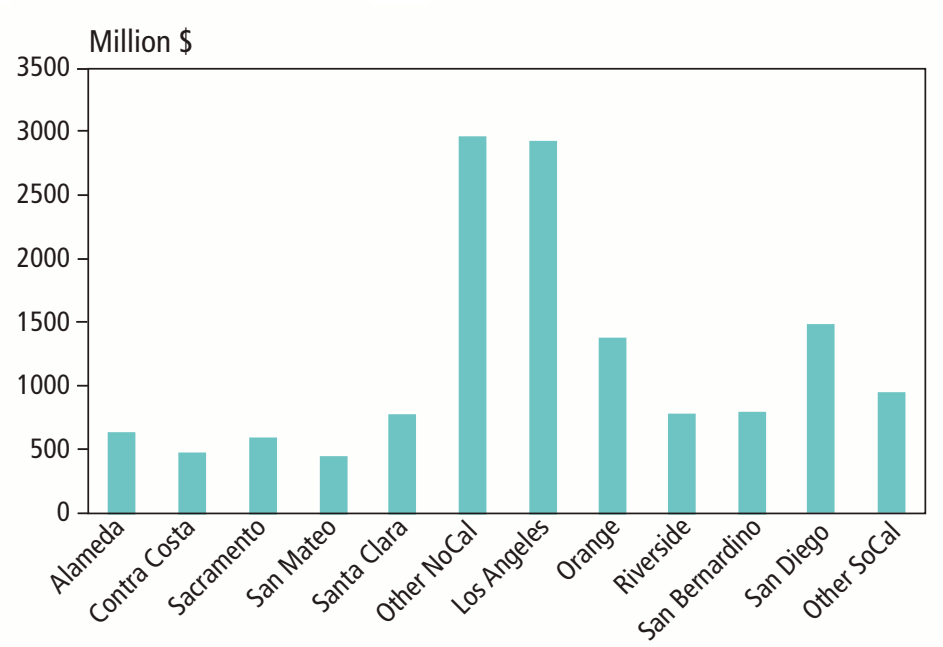

California. Per capita taxable transactions for lumber and building materials were $\$ 414$ (California State Board of Equalization 2000).

Although most lumber production in California takes place in about 12 counties in the northern part of the state, almost 60 percent of expenditures on lumber and building materials takes place in Southern California'2 (Figure 17). As shown in Figure 18, the largest taxable sales of lumber and building materials take place in Los Angeles County, followed by San Diego and Orange Counties (California State Board of Equalization 2000).

Figure 18. Taxable sales of lumber and building materials by county (sales for resale are excluded) (California State Board of Equalization 2000b). 


\section{CONCLUSIONS}

In 1994 the net volume of growing stock in California was estimated to be $340 \mathrm{BBF}$, and annual growth was estimated at $8 \mathrm{BBF}$, or 2.4 percent. The timber harvest in 2000 was 2 BBF, significantly less than the highest timber harvest on record, 6 BBF in 1955, or the almost $5 \mathrm{BBF}$ of 1988. In the 1990s, the downward trend in timber harvest was attributable to the declining harvest of timber on public lands, whereas private harvest levels stayed relatively stable (California Board of Equalization 1991-2000, 2001).

Consolidation and increasing efficiency in the forest products industry has significantly decreased the number of mills operating in California. The production of forest products and employment in the forest industry in the state, however, have not undergone so pronounced a decline. Both board and pulp production in California have diminished, but, especially since the mid-1990s, lumber production has stabilized at about 3 BBF per year.

The consumption of most forest products increased steadily during the 1990s. For example, estimated lumber consumption in California was almost 9 BBF per year. This suggests that about one-third of the lumber consumed was produced in California. California producers' share of state consumption of other forest products seems to be smaller than for lumber.

The overall economic impact of forestry and the forest industry is not very great in California. The forest products industry contributes only about 1 percent to total personal income, value added, and employment figures in the state. There are considerable regional differences in the relative economic effects of the forest products industry, however. Economic impact results indicate that the forest products industry contributes almost one-sixth of all employment and income in many Northern California counties. 


\section{APPENDICES}

Appendix A. Average stumpage prices for sawtimber sold on National Forests in Pacific Southwest Region* 1988-1998

\begin{tabular}{|c|c|c|c|c|c|c|c|}
\hline Year & $\begin{array}{l}\text { Douglas- } \\
\text { fir }\end{array}$ & $\begin{array}{c}\text { Ponderosa } \\
\text { \& Jeffrey } \\
\text { pines }\end{array}$ & $\begin{array}{l}\text { Sugar } \\
\text { pine }\end{array}$ & $\begin{array}{l}\text { Lodgepole } \\
\text { pine }\end{array}$ & Cedars & $\begin{array}{l}\text { True } \\
\text { firs }\end{array}$ & $\begin{array}{c}\text { All } \\
\text { species }\end{array}$ \\
\hline & \multicolumn{7}{|c|}{$-\$ / M B F$} \\
\hline 1988 & 95.64 & 182.14 & 260.43 & 43.20 & 190.90 & 68.89 & 135.65 \\
\hline 1989 & 201.26 & 291.96 & 289.15 & 57.02 & 153.30 & 88.30 & 177.60 \\
\hline 1990 & 218.91 & 217.62 & 285.13 & 84.12 & 231.48 & 85.02 & 166.25 \\
\hline 1991 & 186.62 & 237.62 & 241.25 & 80.05 & 184.64 & 83.08 & 156.70 \\
\hline 1992 & 320.19 & 292.30 & 491.64 & 90.80 & 374.41 & 156.15 & 234.05 \\
\hline 1993 & 390.17 & 535.17 & 598.17 & 163.70 & 245.24 & 272.75 & 367.30 \\
\hline 1994 & 416.25 & 291.34 & 625.19 & 165.10 & 189.98 & 159.36 & 241.46 \\
\hline 1995 & 250.92 & 158.36 & 396.82 & 105.64 & 120.08 & 171.00 & 186.16 \\
\hline 1996 & 189.36 & 299.48 & 318.08 & 53.61 & 135.26 & 182.11 & 184.12 \\
\hline 1997 & 183.17 & 237.48 & 212.37 & 71.66 & 114.66 & 181.90 & 169.37 \\
\hline 1998 & 172.89 & 182.66 & 177.47 & 47.98 & 183.87 & 135.01 & 134.71 \\
\hline
\end{tabular}

Source: Warren 2000, 2001.

* Pacific Southwest Region includes California and Hawaii. 


\begin{tabular}{|c|c|c|c|c|}
\hline \multirow[t]{2}{*}{ Year } & Industry* & Payroll & $\begin{array}{c}\text { Cost of } \\
\text { materials }\end{array}$ & $\begin{array}{l}\text { Total capital } \\
\text { expenditures }\end{array}$ \\
\hline & & & $\$$ million- & \\
\hline \multirow[t]{12}{*}{1993} & Lumber and wood products & $1,167.3$ & $4,448.3$ & 89.4 \\
\hline & Logging & 117.7 & 396.5 & 11.6 \\
\hline & Sawmills and planing mills & 357.1 & $1,757.9$ & 44.7 \\
\hline & Millwork, plywood, and structural & 395.5 & $1,360.1$ & 17.9 \\
\hline & Wood containers & 77.7 & 252.3 & 3.9 \\
\hline & Wood buildings and mobile homes & 63.8 & 194.7 & 2.0 \\
\hline & Misc. wood products & 155.3 & 486.8 & 9.2 \\
\hline & Paper and allied products & $1,208.8$ & $4,380.1$ & 264.7 \\
\hline & Paper mills & $\mathrm{D}$ & D & D \\
\hline & Paperboard mills & 71.9 & 295.9 & 17.1 \\
\hline & Paperboard containers and boxes & 592.6 & $2,275.2$ & 71.5 \\
\hline & Misc. converted paper products & 443.3 & $1,484.1$ & 76.9 \\
\hline \multirow[t]{12}{*}{1994} & Lumber and wood products & $1,253.0$ & $4,428.6$ & 100.7 \\
\hline & Logging & 118.5 & 374.2 & 17.3 \\
\hline & Sawmills and planing mills & 338.5 & $1,594.6$ & 40.3 \\
\hline & Millwork, plywood, and structural & 477.8 & $1,475.7$ & 25.7 \\
\hline & Wood containers & 84.6 & 268.4 & 4.4 \\
\hline & Wood buildings and mobile homes & 65.9 & 202.1 & 0.9 \\
\hline & Misc. wood products & 167.7 & 513.7 & 12.0 \\
\hline & Paper and allied products & $1,228.3$ & $4,942.7$ & 281.0 \\
\hline & Paper mills & D & D & $\mathrm{D}$ \\
\hline & Paperboard mills & 76.1 & 374.6 & 51.2 \\
\hline & Paperboard containers and boxes & 599.6 & $2,543.3$ & 112.7 \\
\hline & Misc. converted paper products & 464.0 & $1,632.2$ & 76.9 \\
\hline \multirow[t]{12}{*}{1995} & Lumber and wood products & $1,204.2$ & $4,134.0$ & 172.3 \\
\hline & Logging & 113.4 & 305.4 & 27.5 \\
\hline & Sawmills and planing mills & 317.1 & $1,413.4$ & 87.3 \\
\hline & Millwork, plywood, and structural & 459.1 & $1,375.4$ & 34.0 \\
\hline & Wood containers & 84.4 & 262.7 & 4.8 \\
\hline & Wood buildings and mobile homes & 60.1 & 182.5 & 0.7 \\
\hline & Misc. wood products & 170.0 & 594.6 & 18.0 \\
\hline & Paper and allied products & $1,260.6$ & $5,804.9$ & 285.7 \\
\hline & Paper mills & D & D & D \\
\hline & Paperboard mills & 77.0 & 437.2 & 50.7 \\
\hline & Paperboard containers and boxes & 618.3 & $3,055.5$ & 98.7 \\
\hline & Misc. converted paper products & 470.5 & $1,781.1$ & 96.8 \\
\hline \multirow[t]{12}{*}{1996} & Lumber and wood products & $1,247.3$ & $4,247.4$ & 169.7 \\
\hline & Logging & 100.8 & 294.0 & 30.4 \\
\hline & Sawmills and planing mills & 330.6 & $1,481.5$ & 64.6 \\
\hline & Millwork, plywood, and structural & 478.1 & $1,365.5$ & 46.7 \\
\hline & Wood containers & 90.4 & 276.1 & 4.2 \\
\hline & Wood buildings and mobile homes & 71.9 & 205.1 & 1.4 \\
\hline & Misc. wood products & 175.5 & 625.2 & 22.4 \\
\hline & Paper and allied products & $1,338.3$ & $5,266.9$ & 259.8 \\
\hline & Paper mills & D & D & D \\
\hline & Paperboard mills & 78.9 & 352.5 & 32.8 \\
\hline & Paperboard containers and boxes & 665.2 & $2,734.7$ & 100.8 \\
\hline & Misc. converted paper products & 503.8 & $1,777.7$ & 99.8 \\
\hline \multirow[t]{7}{*}{1997} & Wood product mfg. & $1,015.7$ & $3,720.1$ & 140.2 \\
\hline & Sawmills and wood preservation & 272.2 & $1,275.9$ & 56.6 \\
\hline & Veneer, plywood, and engineered wood product mfg. & 144.2 & 469.1 & 20.9 \\
\hline & Other wood product mfg. & 599.3 & $1,975.2$ & 62.7 \\
\hline & Paper mfg. & $1,264.0$ & $4,794.9$ & 257.6 \\
\hline & Pulp, paper and paperboard mills & 200.6 & 866.8 & 47.8 \\
\hline & Converted paper product mfg. & $1,063.4$ & $3,928.1$ & 209.8 \\
\hline \multirow[t]{7}{*}{1998} & Wood product mfg. & $1,032.0$ & $3,645.4$ & 145.2 \\
\hline & Sawmills and wood preservation & 276.9 & $1,287.7$ & 78.2 \\
\hline & Veneer, plywood, and engineered wood product mfg. & 140.7 & 417.8 & 12.5 \\
\hline & Other wood product mfg. & 614.4 & $1,940.0$ & 54.5 \\
\hline & Paper mfg. & $1,273.2$ & $5,243.1$ & 446.2 \\
\hline & Pulp, paper, and paperboard mills & 199.0 & 848.8 & 64.8 \\
\hline & Converted paper product mfg. & $1,074.3$ & $4,394.2$ & 381.4 \\
\hline
\end{tabular}

Source: U.S. Census Bureau 1995-2000a, 2001.

*SIC 24 Lumber and wood products, SIC 26 Paper and allied products, NAICS 321 Wood product manufacturing, NAICS 322 Paper manufacturing.

D. Withheld to avoid disclosing data of individual companies; data are included in higher level totals. 
Appendix C. California-Nevada lumber production by species, 1990-1999, in million board feet (MMBF)

\begin{tabular}{|r|r|r|r|r|r|r|r|r|r|}
\hline & $\begin{array}{c}\text { Douglas- } \\
\text { fir }\end{array}$ & \multicolumn{1}{c|}{$\begin{array}{c}\text { Hem- } \\
\text { fir }\end{array}$} & \multicolumn{1}{|c|}{$\begin{array}{c}\text { Incense } \\
\text { cedar }\end{array}$} & $\begin{array}{c}\text { Other } \\
\text { softwood }\end{array}$ & $\begin{array}{c}\text { Ponderosa } \\
\text { pine }\end{array}$ & Redwood & \multicolumn{1}{c|}{$\begin{array}{c}\text { Sitka } \\
\text { spruce }\end{array}$} & \multicolumn{1}{c}{$\begin{array}{c}\text { Sugar } \\
\text { pine }\end{array}$} \\
\hline 1990 & 1,381 & 1,228 & 162 & 3 & 830 & 1,073 & 0 & 304 \\
\hline 1991 & 1,135 & 1,065 & 136 & 0 & 702 & 886 & 3 & 291 \\
\hline 1992 & 1,113 & 1,035 & 154 & 0 & 666 & 803 & 3 & 223 \\
\hline 1993 & 968 & 917 & 138 & 1 & 656 & 707 & 0 & 152 \\
\hline 1994 & 948 & 906 & 138 & 9 & 604 & 782 & 0 & 134 \\
\hline 1995 & 822 & 815 & 131 & 9 & 564 & 733 & 0 & 95 \\
\hline 1996 & 851 & 801 & 126 & 15 & 563 & 770 & 9 & 122 \\
\hline 1997 & 989 & 879 & 136 & 15 & 452 & 824 & 0 & 137 \\
\hline 1998 & 968 & 771 & 145 & 12 & 438 & 752 & 0 & 102 \\
\hline 1999 & 981 & 888 & 157 & 8 & 392 & 658 & 10 & 122 \\
\hline
\end{tabular}

Source:WWPA 1997, 1999

\section{Appendix D. Economic impact of forestry and related processing industries in California in 1999}

\begin{tabular}{|c|c|c|c|c|c|c|c|c|c|c|}
\hline \multirow[b]{2}{*}{ Sector(s) } & \multirow[b]{2}{*}{ Description } & \multirow[b]{2}{*}{$\begin{array}{c}\text { Sales to final } \\
\text { demand/total } \\
\text { output } \\
(\$ 1,000)\end{array}$} & \multicolumn{4}{|c|}{ Multipliers } & \multicolumn{4}{|c|}{ Impact on California } \\
\hline & & & $\begin{array}{c}\text { Output } \\
\text { (type II) }\end{array}$ & $\begin{array}{l}\text { Total } \\
\text { income } \\
\text { (total } \\
\text { coef.) }\end{array}$ & $\begin{array}{l}\text { Value } \\
\text { added } \\
\text { (total } \\
\text { coef.) }\end{array}$ & $\begin{array}{c}\text { Employment } \\
\text { (jobs/ } \\
\$ 1,000,000)\end{array}$ & $\begin{array}{c}\text { Sales } \\
(\$ 1,000)\end{array}$ & $\begin{array}{c}\text { Total } \\
\text { income } \\
(\$ 1,000)\end{array}$ & $\begin{array}{c}\text { Value } \\
\text { added } \\
(\$ 1,000)\end{array}$ & $\begin{array}{c}\text { Employment } \\
\text { (number of } \\
\text { jobs) }\end{array}$ \\
\hline 24 & Forestry products & 752,020 & 1.8497 & 0.8339 & 0.9682 & 22.1766 & $1,391,005$ & 627,112 & 728,131 & 16,677 \\
\hline 133 & Logging camps and logging contractors & 155,352 & 1.6240 & 0.7314 & 0.7726 & 11.1780 & 252,287 & 113,620 & 120,017 & 1,737 \\
\hline $134,135,136$ & Sawmills and planing mills & 285,910 & 2.0660 & 0.8870 & 0.9595 & 15.2759 & 590,687 & 253,613 & 271,757 & 4,368 \\
\hline 137 & Millwork & 275,586 & 2.1792 & 1.0363 & 1.1119 & 22.4594 & 600,549 & 285,580 & 306,412 & 6,189 \\
\hline 138 & Wood kitchen cabinets & 205,070 & 2.0738 & 1.0510 & 1.1206 & 21.9644 & 425,265 & 215,524 & 229,805 & 4,504 \\
\hline 139 & Veneer and plywood & 19,772 & 1.9819 & 0.8480 & 0.9074 & 16.9108 & 39,185 & 16,766 & 17,940 & 334 \\
\hline 140 & Structural wood members, N.E.C. & 88,686 & 2.1605 & 0.9624 & 1.0358 & 19.4954 & 191,603 & 85,349 & 91,857 & 1,729 \\
\hline 141,142 & Wood containers, pallets, skids & 137,916 & 2.1307 & 1.0491 & 1.1212 & 24.3753 & 293,858 & 144,681 & 154,627 & 3,362 \\
\hline 143 & Mobile homes & 839,283 & 1.9400 & 0.9087 & 0.9682 & 15.5997 & $1,628,180$ & 762,683 & 812,611 & 13,093 \\
\hline 144 & Prefabricated wood buildings & 232,891 & 2.1842 & 0.9402 & 1.0114 & 19.6577 & 508,684 & 218,954 & 235,553 & 4,578 \\
\hline 145 & Wood preserving & 4,995 & 2.2579 & 0.8032 & 0.8745 & 14.6941 & 11,278 & 4,012 & 4,368 & 73 \\
\hline 146 & Reconstituted wood products & 17,666 & 2.1011 & 0.9150 & 0.9789 & 13.8027 & 37,117 & 16,164 & 17,294 & 244 \\
\hline 147 & Wood products & 474,980 & 2.1012 & 1.0219 & 1.0921 & 22.3339 & 998,029 & 485,366 & 518,746 & 10,608 \\
\hline 148 & Wood household N.E.C. furniture & $1,126,232$ & 2.1640 & 0.9794 & 1.0479 & 23.0867 & $2,437,189$ & $1,103,067$ & $1,180,141$ & 26,001 \\
\hline 152 & Wood TV and radio cabinets & 42,618 & 2.1690 & 1.0224 & 1.0933 & 25.9339 & 92,438 & 43,573 & 46,596 & 1,105 \\
\hline 154 & Wood office furniture & 76,394 & 2.2087 & 1.0373 & 1.1112 & 22.9728 & 168,727 & 79,244 & 84,890 & 1,755 \\
\hline 156 & Public building furniture & 9,883 & 2.2568 & 0.9285 & 0.9963 & 17.0899 & 22,304 & 9,176 & 9,847 & 169 \\
\hline 157 & Wood partitions and fixtures & 89,539 & 2.1578 & 1.0385 & 1.1061 & 19.9781 & 193,205 & 92,985 & 99,040 & 1,789 \\
\hline 161,162 & Pulp and paper mills & 982,427 & 2.0715 & 0.9128 & 0.9803 & 13.8185 & $2,035,051$ & 896,782 & 963,050 & 13,576 \\
\hline 163 & Paperboard mills & 532,760 & 2.1130 & 0.8184 & 0.8864 & 12.7441 & $1,125,705$ & 436,007 & 472,254 & 6,790 \\
\hline 164 & Paperboard containers and boxes & $5,165,608$ & 1.7149 & 0.6879 & 0.7442 & 12.1733 & $8,858,286$ & $3,553,304$ & $3,844,241$ & 62,883 \\
\hline 165 & Paper coated and laminated packaging & 327,887 & 1.9609 & 0.8065 & 0.8652 & 13.8706 & 642,946 & 264,427 & 283,704 & 4,548 \\
\hline 166 & Paper coated and laminated, N.E.C. & 651,212 & 1.9040 & 0.9426 & 1.0032 & 12.1387 & $1,239,917$ & 613,819 & 653,314 & 7,905 \\
\hline 168 & Bags, paper & 165,383 & 2.0129 & 0.8213 & 0.8810 & 17.8391 & 332,905 & 135,821 & 145,708 & 2,454 \\
\hline 169 & Die-out paper and board & 605,324 & 1.7591 & 0.7593 & 0.8173 & 14.0213 & $1,064,808$ & 459,649 & 494,729 & 8,487 \\
\hline 170 & Sanitary paper products & 901,988 & 1.6884 & 0.7162 & 0.7649 & 8.7719 & $1,522,906$ & 646,027 & 689,937 & 7,912 \\
\hline 171 & Envelopes & 377,160 & 1.8226 & 0.7779 & 0.8374 & 14.6548 & 687,409 & 293,381 & 315,834 & 5,527 \\
\hline 172 & Stationery products & 96,981 & 1.6180 & 0.6551 & 0.7041 & 10.2004 & 156,914 & 63,530 & 68,280 & 989 \\
\hline \multirow[t]{3}{*}{173} & Converted paper products, N.E.C. & 563,624 & 1.7910 & 0.8016 & 0.8611 & 13.5839 & $1,099,440$ & 451,810 & 485,361 & 7,656 \\
\hline & Total & $15,205,146$ & & & & & $28,557,876$ & $12,372,026$ & $13,346,041$ & 227,042 \\
\hline & $\%$ of California's Gross State Product & & & & & & & $1.13 \%$ & $1.09 \%$ & $1.44 \%$ \\
\hline
\end{tabular}

California Personal Income, 1999 (\$1,000): 1,093,196,182

California Gross State Product, 1999 (\$1,000): 1,229,098,000

California Employment, 1999 (includes salary workers, employers, own-account workers, unpaid family workers, and workers directly involved in work stoppages): 15,731,700

Sources:

California Personal Income, 1999: U.S. Bureau of Economic Analysis: Released: June 11, 2001.

California Gross State Product, 1999: Bureau of Economic Analysis: Released: June 4, 2001

California Employment, 1999: Labor Market Information Division, EDD, Sacramento. 
Appendix E. Fourteen-county region, ${ }^{*}$ California: Economic impact of forestry and related processing industries

\begin{tabular}{|c|c|c|c|c|c|c|c|c|c|c|}
\hline \multirow[b]{2}{*}{ Sector(s) } & \multirow[b]{2}{*}{ Description } & \multirow[b]{2}{*}{$\begin{array}{c}\text { Sales to final } \\
\text { demand/total } \\
\text { output, 1999 } \\
(\$ 1,000)\end{array}$} & \multicolumn{4}{|c|}{ Multipliers } & \multicolumn{4}{|c|}{ Impact on California } \\
\hline & & & $\begin{array}{l}\text { Output } \\
\text { (type II) }\end{array}$ & $\begin{array}{l}\text { Total } \\
\text { income } \\
\text { (total } \\
\text { coef.) }\end{array}$ & $\begin{array}{l}\text { Value } \\
\text { added } \\
\text { (total } \\
\text { coef.) }\end{array}$ & $\begin{array}{c}\text { Employment } \\
\text { (jobs/ } \\
\$ 1,000,000)\end{array}$ & $\begin{array}{c}\text { Sales } \\
(\$ 1,000)\end{array}$ & $\begin{array}{c}\text { Total } \\
\text { income } \\
(\$ 1,000)\end{array}$ & $\begin{array}{l}\text { Value } \\
\text { added } \\
(\$ 1,000)\end{array}$ & $\begin{array}{c}\text { Employment } \\
\text { (number } \\
\text { of jobs) }\end{array}$ \\
\hline 24 & Forestry products & 624,119 & 1.6670 & 0.7661 & 0.8951 & 21.4359 & $1,040,421$ & 478,139 & 558,623 & 13,379 \\
\hline 133 & Logging camps and logging contractors & 137,885 & 1.4742 & 0.6518 & 0.6863 & 11.7699 & 203,274 & 89,878 & 94,627 & 1,623 \\
\hline $134,135,136$ & Sawmills and planing mills & $1,661,112$ & 2.0171 & 0.8523 & 0.9105 & 17.3867 & $3,350,637$ & $1,415,724$ & $1,512,505$ & 28,881 \\
\hline 137 & Millwork & 188,715 & 2.0606 & 0.9538 & 1.0210 & 25.3438 & 388,875 & 180,001 & 192,676 & 4,783 \\
\hline 138 & Wood kitchen cabinets & 16,305 & 1.9725 & 0.9565 & 1.0185 & 25.5448 & 32,162 & 15,597 & 16,607 & 417 \\
\hline 139 & Veneer and plywood & 35,847 & 1.9456 & 0.8547 & 0.9105 & 18.9312 & 69,745 & 30,640 & 32,640 & 679 \\
\hline 140 & Structural wood members, N.E.C. & 21,573 & 2.1227 & 0.9302 & 0.9977 & 22.5015 & 45,793 & 20,067 & 21,525 & 485 \\
\hline 141,142 & Wood containers, pallets, skids & 11,470 & 2.0973 & 1.0096 & 1.0766 & 26.9847 & 24,057 & 11,580 & 12,349 & 310 \\
\hline 143 & Mobile homes & 865 & 1.5904 & 0.7697 & 0.8168 & 14.9113 & 1,376 & 666 & 707 & 13 \\
\hline 144 & Prefabricated wood buildings & 7,869 & 2.0238 & 0.8414 & 0.9031 & 21.8628 & 15,926 & 6,621 & 7,107 & 172 \\
\hline 145 & Wood preserving & 6,188 & 2.1699 & 0.7810 & 0.8459 & 16.9018 & 13,428 & 4,833 & 5,235 & 105 \\
\hline 146 & Reconstituted wood products & 102,879 & 1.8090 & 0.7834 & 0.8356 & 13.9827 & 186,104 & 80,598 & 85,965 & 1,439 \\
\hline 147 & Wood products, N.E.C. & 13,028 & 1.9823 & 0.9800 & 1.0430 & 23.8856 & 25,826 & 12,768 & 13,589 & 311 \\
\hline 148 & Wood household furniture & 2,174 & 1.9461 & 0.7854 & 0.8417 & 26.6714 & 4,230 & 1,707 & 1,830 & 58 \\
\hline 154 & Wood office furniture & 628 & 1.9837 & 0.7714 & 0.8324 & 28.2355 & 1,245 & 484 & 522 & 18 \\
\hline 156 & Public building furniture & 1,728 & 1.6844 & 0.5901 & 0.6352 & 16.2492 & 2,911 & 1,020 & 1,098 & 28 \\
\hline 157 & Wood partitions and fixtures & 1,101 & 1.8474 & 0.8426 & 0.8963 & 21.6700 & 2,034 & 928 & 987 & 24 \\
\hline 161,162 & Pulp and paper mills & 306,978 & 1.8060 & 0.7933 & 0.8495 & 14.2013 & 554,394 & 243,536 & 260,781 & 4,359 \\
\hline 164 & Paperboard containers and boxes & 14,555 & 1.6567 & 0.5562 & 0.6035 & 14.7069 & 24,114 & 8,096 & 8,784 & 214 \\
\hline 166 & Paper coated and laminated, N.E.C. & 329 & 1.5888 & 0.7599 & 0.8072 & 12.4472 & 523 & 250 & 266 & 4 \\
\hline \multirow[t]{3}{*}{173} & Converted paper products, N.E.C. & 126,348 & 1.6491 & 0.7153 & 0.7669 & 15.1743 & 208,359 & 90,376 & 96,902 & 1,917 \\
\hline & Total & $3,281,699$ & & & & & $6,195,433$ & $2,693,509$ & $2,925,324$ & 59,217 \\
\hline & $\%$ of fourteen-county total & & & & & & & $13.25 \%$ & $11.59 \%$ & $15.59 \%$ \\
\hline
\end{tabular}

*Fourteen counties included are Butte, Del Norte, Humboldt, Lassen, Mendocino, Modoc, Nevada, Plumas, Shasta, Sierra, Siskiyou, Tehama, Trinity, and Yuba.

Fourteen-county personal income, $1999(\$ 1,000): 20,323,456$

Estimated fourteen-county value added, 1999 (\$1,000): 25,242,285

Fourteen-county employment, 1999 (includes salary workers, employers, own-account workers, unpaid family workers, and workers directly involved in work stoppages): 379,850

Sources: Fourteen-County Personal Income, 1999: U.S. Bureau of Economic Analysis, Updated June 25, 2001.

Estimated Fourteen-County Value Added, 1999: Applying 1999 State Ratio of GSP to Personal Income to 1999 Fourteen-County Personal Income.

Fourteen-County Employment, 1999: Labor Market Information Division, EDD, Sacramento.

Market Value of Timber Harvest, 1999: California State Board of Equalization.

\section{REFERENCES}

Bellis, A. 2001. California biomass energy facilities. Unpublished report. University of California Forest Products Laboratory, Richmond, California.

Bolsinger, C. L. 1980. California forests: Trends, problems, and opportunities. U.S. Forest Service, Resource Bulletin PNW-89.

California Department of Food and Agriculture. 2001. CDFA Resource Directory 2000. http://www.cdfa.ca.gov/docs/ResourceDirectory.pdf

California Energy Commission. 2001. http://www.energy.ca.gov/index.html

California Energy Commission. 2002. 2002-2012 Electricity outlook report. February 2002. P700-01-004F.

California State Board of Equalization. 1981-2000. California timber harvest by county. http://www.boe.ca.gov/proptaxes/timbertax.htm

California State Board of Equalization. 2000. Taxable sales in California (sales and use tax) in 1999. http://www.boe.ca.gov/news/tsalescont.htm

California State Board of Equalization. 2001. California timber harvest by county. http://www.boe.ca.gov/proptaxes/timbertax.htm

Fire and Resource Assessment Program (FRAP). 2001. Updated California forest statistics abstract. Sacramento: California Department of Forestry and Fire Protection. http://frap.cdf.ca.gov/projects/forest_statistic_abstract/statistic_abstract.html

Forest and Rangeland Resources Assessment Program (FRRAP). 1988. California's forests and rangelands: Growing conflict over changing uses. Sacramento: California Department of Forestry and Fire Protection. 
Helms, J., ed. 1998. The dictionary of forestry. Bethesda: SAF and CABI Publishing.

Hetemäki, L. 1999. Information technology and paper demand scenarios. In M. Palo and J. Uusivuori (eds.). World forests, society, and environment. Dordrecht: Kluwer Academic Publishers.

Howard, J. L. 2001. U.S. timber production, trade, consumption, and price statistics. U.S. Forest Service Research Paper FPL-RP-595.

McWilliams, B., and G. Goldman. 1994. The forest products industries in California: Their impact on the state economy. College of Natural Resources, University of California, Berkeley. Publication CNR002.

Morris, G. 1999. Do we need a biomass energy policy? The California experience. In Biomass: A growth opportunity in green energy and value-added products. Pergamon, Elsevier Science vol. 1: 1-7.

Shelly, J., D. M. Lubin, and A. Johl. 1999. 1999 California hardwood industry profile: Final report. Richmond, CA: University of California Forest Products Laboratory. Technical Report 35.01.454.

Southern Forest Products Association (SFPA). 2000. Industry statistics 2000. http://www.sfpa.org/IndStat.htm

Statistics Canada. 2001. Canadian custom statistics. http://www.statcan.ca/

U.S. Census Bureau. 1995-2000a. Annual survey of manufactures. http://www.census.gov/mcd/asmhome.html

U.S. Census Bureau. 2000b. County business patterns 1999. http://www.census.gov/epcd/cbp/view/cbpview.html

U.S. Census Bureau. 2001. Annual survey of manufactures. http://www.census.gov/mcd/asmhome.html

U.S. Department of Commerce Bureau of Economic Analysis. 2001a. Gross state product data. http://www.bea.doc.gov/bea/regional/gsp/

U.S. Department of Commerce Bureau of Economic Analysis. 2001b. National accounts data. http://www.bea.doc.gov/bea/dnl.htm

Waddell, K. L., and P. M. Bassett. 1996. Timber resource statistics for the north coast resource area of California, 1994. U.S. Forest Service, Pacific Northwest Research Station. Resource Bulletin PNW-RB-214.

Waddell, K. L., and P. M. Bassett. 1997a. Timber resource statistics for the Sacramento resource area of California, 1994. U.S. Forest Service, Pacific Northwest Research Station. Resource Bulletin PNW-RB-220.

Waddell, K. L., and P. M. Bassett. 1997b. Timber resource statistics for the central coast resource area of California, 1994. U.S. Forest Service, Pacific Northwest Research Station. Resource Bulletin PNW-RB-221.

Waddell, K. L., and P. M. Bassett. 1997c. Timber resource statistics for the north interior resource area of California, 1994. U.S. Forest Service, Pacific Northwest Research Station. Resource Bulletin PNW-RB-222.

Waddell, K. L., and P. M. Bassett. 1997d. Timber resource statistics for the San Joaquin and southern resource area of California, 1994. U.S. Forest Service, Pacific Northwest Research Station. Resource Bulletin PNW-RB-224.

Ward, F. R. 1995. California's forest products industry: 1992. U.S. Forest Service, Pacific Northwest Research Station. Resource Bulletin PNW-RB-206.

Warren, D. D. 2000. Production, prices, employment, and trade in northwest forest industries, all quarters 1998. U.S. Forest Service, Pacific Northwest Research Station. Resource Bulletin PNW-RB-231.

Warren, D. D. 2001. Production, prices, employment, and trade in northwest forest industries, all quarters 1999. U.S. Forest Service, Pacific Northwest Research Station. Resource Bulletin PNW-RB-235.

WWPA. 1997. 1997 Statistical yearbook of the western lumber industry. Western Wood Products Association, Economic Services Division.

WWPA. 1999. 1999 Statistical yearbook of the western lumber industry. Western Wood Products Association, Economic Services Division. 


\section{FOR MORE INFORMATION}

You'll find detailed information on many aspects of forestry and forest products in these titles and in other publications, slide sets, videos, and CD-ROMs from UC ANR:

Forest and Right-of-Way Pest Control, publication 3336

Prospects for Supply of Private Timber in California, publication 1931

To order these products, visit our online catalog at http://anrcatalog.ucdavis.edu. You can also place orders by mail, phone, or fax, or request a printed catalog of publications, slide sets, videos, and CD-ROMs from

University of California Agriculture and Natural Resources Communication Services 6701 San Pablo Avenue, 2nd Floor Oakland, California 94608-1239

Telephone: (800) 994-8849 or (510) 642-2431, FAX: (510) 643-5470 E-mail inquiries: danrcs@ucdavis.edu An electronic version of this publication is available on the ANR Communication Services Web site at http://anrcatalog.ucdavis.edu.

\section{Publication 8070}

(C) 2003 by the Regents of the University of California, Division of Agriculture and Natural Resources. All rights reserved.

The University of California prohibits discrimination against or harassment of any person employed by or seeking employment with the University on the basis of race, color, national origin, religion, sex, physical or mental disability, medical condition (cancer-related or genetic characteristics), ancestry, marital status, age, sexual orientation, citizenship, or status as a covered veteran (special disabled veteran, Vietnam-era veteran or any other veteran who served on active duty during a war or in a campaign or expedition for which a campaign badge has been authorized).

University Policy is intended to be consistent with the provisions of applicable State and Federal laws.

Inquiries regarding the University's nondiscrimination policies may be directed to the Affirmative Action/Staff Personnel Services Director, University of California, Agriculture and Natural Resources, 300 Lakeside Drive, 6th Floor, Oakland, CA 94612-3550 (510) 987-0096. For information about obtaining this publication, call (800) 994-8849. For information on downloading, call (530) 754-5112.

pr-7/03-WJC/CR

ISBN 978-1-60107-248-1

This publication has been anonymously peer reviewed for technical accuracy by University of California scientists and other qualified professionals. This review process was managed by the ANR Associate Editor for Natural Resources. 